Ocean Sci. Discuss., doi:10.5194/os-2016-2, 2016

Manuscript under review for journal Ocean Sci.

Published: 3 February 2016

(c) Author(s) 2016. CC-BY 3.0 License.

\title{
Total suspended matter derived from MERIS data as indicator for coastal processes in the Baltic Sea
}

\author{
D. Kyryliuk ${ }^{1}$, S. Kratzer ${ }^{1}$ \\ ${ }^{1}$ Department of Ecology, Environment and Plant Sciences, Stockholm University, Stockholm, 106 91, Sweden \\ 5 Correspondence to: D. Kyryliuk (dmytro.kyryliuk@su.se)
}

Abstract. Total suspended matter (TSM) is an indicator of coastal processes and can be retrieved reliably from MERIS

(Medium Resolution Imaging Spectrometer) data. In this project we used MERIS TSM data from a Swedish coastal monitoring system www.vattenkvalitet.se to evaluate the physical extend of coastal processes.

The data set consisted of all viable MERIS scenes during summer (June-August) 2009-2011, covering the whole Baltic Sea

area. Monthly composite images were produced for each year, and the monthly composites were subsequently evaluated with regards to terrestrial influence, and the typical features caused by cyanobacteria blooms (typically during July and August).

Next, a composite image from early June 2011 was generated in order to exclude a possible influence from cyanobacteria on the patterns of TSM distribution. This early June composite was then used as a basis to evaluate the extent of terrestrial influence using the NW Baltic Proper (Swedish coastal areas) and the SE Baltic Proper (Latvian, Lithuanian and Polish coastal waters) as examples.

In both areas the averaged TSM scenes from early June were used to extract transects of TSM data perpendicular to the coast, spanning from coastal to offshore waters. Based on previous bio-optical research in the NW Baltic Sea and on further statistical analysis of MERIS scenes local coastal water thresholds were defined for different areas in the Baltic Sea. Using these local thresholds, it was found that coastal processes in the NW Baltic Sea extend to approximately 15-27 km off-shore, whereas in the SE Baltic Sea the coastal influence extended to about twice the distance i.e. to about 34-52 km off-shore.

Next, the trendlines of TSM distribution along transects was evaluated mathematically. The trend line for the NW Baltic proper was best described by a polynomial equation, whereas the trend line from the transect in SE coastal waters was best described logarithmically in areas of high resuspension. These differing trends indicate different hydrological regimes in the two areas, which are mostly driven by a combination of land run-off distributed by diffusional processes, and coastal dynamics driven by local wind exposure.

The results demonstrate that ocean colour remote sensing can provide important information for Baltic Sea research and management, as well as for the monitoring of coastal processes. The method allows for an evaluation of the extent of coastal influence, and of seasonal fluctuations in river run-off and phytoplankton dynamics. Furthermore, the concentrations of total suspended matter in the different sub-basins of the entire Baltic Sea can be compared synoptically. 
Ocean Sci. Discuss., doi:10.5194/os-2016-2, 2016

Manuscript under review for journal Ocean Sci.

Published: 3 February 2016

(c) Author(s) 2016. CC-BY 3.0 License.

\section{Introduction}

Coastal waters are highly influenced by coastal run-off and by nutrients from land, stimulating algal and phytoplankton growth (Lessin and Raudsepp 2007). The coastal zone also provides habitats for mariculture and nurseries for fish (Kratzer and Tett, 2009), and has a high recreational value for humans. It is also the area that is most strongly affected by pollutants

5 from land (Cederwall et al. 1990).

For monitoring the water quality status and for management it is important to define the extent of coastal areas and processes. The definition of the coastal zone, however, is a complicated task in the Baltic Sea as there is no clear topographic feature, such as the continental shelve, delineating different water types. The most common definitions for coastal waters are usually based on physical criteria. For example, the coastal zone may be defined as the area where the water depth is less 10 than a fixed value. This approach makes e.g. near-shore and island water bodies part of the coastal zone (Leppäranta, 2009). For management purposes the EU Water Framework Directive (ECE, 2000) defines the coastal zone as: "the surface water on the landward side of a line every point of which is at distance of one nautical mile $(\mathrm{nm})$ on the seaward side from the nearest point of the baseline from which the breadth of territorial waters is measured". This means that it is defined here as a fixed distance to the shore. In reality, however, the coastal zone is larger and may reach much beyond 1 nautical mile as can

15 be seen in satellite images.

The Swedish national definition of the extent of the coastal zone is mostly based on physical criteria and a hydrological model developed by the Swedish Meteorological and Hydrological Institute (SMHI). The physical parameters used as input into SMHI's model are the maximum depth, salinity, stratification, wave exposure, number of days with ice cover, as well as bottom substrate. The model is used for classifying all Swedish coastal waters, and for dividing them into different water bodies that are used by HELCOM for the periodic ecological status assessment (Naturvårdsverket, 2006.).

Coastal areas are rather dynamic systems and require a monitoring approach that can capture the dynamic processes in coastal waters. For example, storm events can lead to a sudden sediment bloom, and a phytoplankton bloom can develop within several days or weeks. These dynamics can be monitored more efficiently by using data derived from ocean colour satellites (Attila et al., 2013; Kahru et al., 2014; Kratzer et al. 2014; Harvey et al., 2015).

25 The Medium Resolution Imaging Spectrometer developed by the European Space Agency (ESA) and launched on ENVISAT in 2002 was the first operational ocean colour sensor that was specifically adapted to monitor coastal zones (Schiller and Doerffer, 1999). Because of its improved spatial and spectral resolution, it was capable to sense the dynamical changes in coastal water quality, and it also has been shown to improve the temporal resolution of water monitoring programs (Kratzer et al, 2014; Harvey et al., 2015), even in areas with relatively frequent cloud cover, such as the Baltic Sea

30 (Isemer and Rozwadowska, 1999; Karlsson, 2003).

One parameter that can be used to identify the extent of the coastal zone is total suspended matter (TSM), which also can be detected from space using ocean colour remote sensing data. Previous bio-optical research has shown that TSM may be used to evaluate the extent of the coastal zone in in-water Baltic Sea waters that are optically dominated by CDOM. Kratzer and 
Ocean Sci. Discuss., doi:10.5194/os-2016-2, 2016

Manuscript under review for journal Ocean Sci.

Published: 3 February 2016

(c) Author(s) 2016. CC-BY 3.0 License.

Tett (2009) developed an optical model that was used to verify a dynamic model describing the distribution of matter in a coastal area. This model assumed diffusion to be the driving force for the distribution of suspended matter, given that tidal influence in the Baltic Sea is almost absent. It was found that diffusional transport of bio-optical variables along an axis perpendicular to the coast can be described using a steady-state model. According to this model the distribution along the

5 axis can be characterized as a low-order polynomial (order 1-3) when particles are transported from an inland source (e.g. sewage treatment plant) into the open sea. The derived optical model defined the extent of the coastal zone in the range of 15 $\mathrm{km}$ for north-western Baltic Sea during the summer period, based on inorganic suspended matter. The authors therefore hypothesized, based on bio-optical in-water measurements that the extend of the coastal zone in the NW Baltic proper should be in the range of tens of kilometres, taking seasonal variations into account, and not $1 \mathrm{~nm}$ as defined by the WFD.

10 TSM can be retrieved with relatively high accuracy from MERIS data (Kratzer and Vinterhav, 2010; Beltran et al., 2014), i.e. with a bias of about $8-16 \%$, dependant on the processor used. In this paper we transpose the idea of the one- dimensional bio-optical model described in Kratzer and Tett (2009) into a two-dimensional model using MERIS data, covering the whole Baltic proper.

The main objectives of this study are to 1) to generally derive mean estimates of total suspended matter load of the different

15 Baltic Sea sub basins using MERIS data, 2) to investigate if MERIS data can be used to evaluate the extent of coastal processes in the Baltic Sea and 3) to compare the extent of the coastal water masses as derived from remote sensing data to the water body classification defined by SMHI, with Baltic Sea bathymetry and marine seabed sediment.

\section{Methods}

Full Resolution (FR) level 2 MERIS data was provided by Brockmann Geomatics AB. The data had been processed by

Brockman Consult (BC), Germany for the CoastColour project and was delivered to the Swedish coastal monitoring system (vattenkvalitet.se). The delivered level 2 data had been processed the following way. MERIS full-resolution level $1 \mathrm{~b}$ data (v.3) was geo-corrected using AMORGOS. This was further processed to level $1 \mathrm{p}$, including radiometric and smile correction, as well as a correction for adjacency effects using ICOL (Santer et al., 2009). A pixel identification tool developed by $\mathrm{BC}$ was used to mask clouds and mixed pixels. Level 2 data was subsequently generated from level 1P using the Case-2 Water Properties processor from Freie Univesität Berlin (FUB processor, Schreoder et al., 2007).

The provided level 2 data covered the entire Baltic Sea region and consisted of all viable MERIS scenes during the summer periods (June-August) 2009-2011. These had already been identified by Brockmann Geomatic AB for inclusion in the Swedish coastal monitoring system. Figure 1 shows a summary of all scenes that were used for the binning procedure (BEAM software) to derive monthly composite images. 
Ocean Sci. Discuss., doi:10.5194/os-2016-2, 2016

Manuscript under review for journal Ocean Sci.

Published: 3 February 2016

(c) Author(s) 2016. CC-BY 3.0 License.

\subsection{Areas of investigation}

During pre-analysis two contrasting areas were chosen each for a case study to evaluate the extent of the coastal zone: the NW Baltic and the SE Baltic proper (Figure 2). The areas were chosen based on differences in run-off, depth, wind exposure and bottom substrates (Kratzer et al., 2011).

\section{$5 \quad 2.2$ Geolocation}

The data used in this project has been geolocated with AMORGOS (Accurate MERIS Ortho Rectified Geo-location Operational Software), developed by ACRI-ST in France. AMORGOS includes a precise orbit determination, instrument pointing and performs an ortho-rectification. Evaluation of AMORGOS processed data compared to manually geo-corrected data was done prior to the study using Ground Control Points in ortho photo images available in digital format from the

10 Swedish National Land Survey. For most evaluation points, AMORGOS generated slightly better accuracy, and a much better overall quality of the correction was achieved.

\subsection{Radiometric correction}

Data needs to be radiometrically calibrated, which initially means that raw data is converted from digital numbers to Top-Ofthe-Atmosphere (TOA) calibrated radiances measured in $\mathrm{mWm}^{-2} \mathrm{sr}^{-1}-\mathrm{nm}^{-1}$. In addition, throughout the lifetime of a sensor the detectors age, which needs to be accounted for by applying a radiometric correction model and coefficients.

\section{$2.4 \mathrm{~L} 2$ processing}

L2 processing consists of atmospheric correction and retrieval of concentration of the water constituents. During recent years, a number of coastal and inland L2 processors have been developed besides the standard MERIS/ESA processor (MEGS) and results have been improved. Further development is an ongoing research topic. Known examples are the Case 2 Regional Processor (C2R) - Doerffer and Schiller. (1999, 2007), the Boreal Lakes Processor (BOR) (Doerffer and Schiller, 2008) and the Eutrophic Lakes Processor (EUL) - Koponen et al. (2008) and Ruiz-Verdu et al. (2008), all three processors developed by HZG, Germany and using identical atmospheric correction algorithms. However, they all have different water quality algorithms, each adapted to a certain water type. Along with these aforementioned processors, the FUB coastal Water Properties Processor from Free University Berlin Schroeder et al. (2007) has also been tested for the Baltic Sea (Kratzer and Vinterhav, 2010; Beltran et al., 2014), the Gulf of Bothnia and for Lakes Vänern, Vättern and Mälaren. FUB generated the best results for all areas and has therefore been used for implementation in the coastal observational system www.vattenkvalitet.se. 
Ocean Sci. Discuss., doi:10.5194/os-2016-2, 2016

Manuscript under review for journal Ocean Sci.

Published: 3 February 2016

(c) Author(s) 2016. CC-BY 3.0 License.

\subsection{L2 Mosaic function}

The entire Baltic Sea is usually not covered by one single MERIS overpass. In order to derive a full image of the Baltic Sea one has to make a mosaic composite image of at least 2 MERIS scenes. Figure 3 shows how the mosaic function in BEAM that is used to generate a mosaic composite image.

\section{$5 \quad 2.6 \mathrm{~L} 3$ processing}

In order to evaluate the extent of the coastal processes and to see seasonal variability in TSM concentration in the Baltic Sea L2 mosaic images for each month were used. The L3 binning function was used to derive averaged monthly mean images (composites) and the spatially and temporally binned products are referred to as L3 data. 'Binning' refers to the process of attributing the contribution of all level 2 pixels in satellite coordinates to a fixed level 3 grid using a geographic reference system (Figure 4). A sinusoidal projection is used to realize a Level 3 grid comprising a fixed number of equal area bins with global coverage.

Monthly means (level 3 products) of the TSM concentration were generated and subsequently used to evaluate the extent of the coastal zones along the whole Swedish coast. The aim was to evaluate if there was a difference in the extent of the coastal zone for different areas and different seasons of the year, which may be caused by differences in precipitation or wind exposure.

\subsection{Using TSM to evaluate the extent of coastal processes}

In situ TSM is usually measured gravimetrically and can be divided into an organic and an inorganic fraction (Strickland and Parson, 1972). Kratzer and Tett (2009) showed that inorganic TSM can be used to identify the break from coastal to open sea water, and the authors used a coastal threshold of $0.05 \mathrm{gm}^{-3}$ for inorganic TSM, which corresponded to about $15 \mathrm{~km}$ offshore. However, inorganic suspended matter is not a standard level-2 product for MERIS. The trend lines in Kratzer and Tett (2009) show that the threshold for TSM should be in the range of about $0.8(+/-0.3) \mathrm{g} \mathrm{m}^{-3}$ in the NW Baltic Sea, corresponding to the distance from the shore where the concentration of inorganic matter also tends towards zero. Using individual MERIS scenes several coastal areas in the Baltic Sea were evaluated with regards to a general coastal threshold for the Baltic Sea. A rough, preliminary statistical analysis showed that $0.6 \mathrm{~g} \mathrm{~m}^{-3}$ is an overall more appropriate threshold for different Baltic Sea basins, which is also within the mean and standard deviation of the local threshold identified for the NW Baltic Proper. A similar threshold of $0.5 \mathrm{~g} \mathrm{~m}^{-3}$ was defined by the NASA SeaWiFS protocol (Mueller and Austin, 1995), to generally identify the transition from Case-1 to Case-2 water masses. As Case-1 a water mass is categorised if total SPM (TSM) concentration is less than $0.5 \mathrm{~g} \mathrm{~m}^{-3}$ (dry weight).

Next, the TSM concentration extracted from MERIS data was used to evaluate the trend of TSM along a gradient from 
Ocean Sci. Discuss., doi:10.5194/os-2016-2, 2016

Manuscript under review for journal Ocean Sci.

Published: 3 February 2016

(c) Author(s) 2016. CC-BY 3.0 License.

perpendicular to the coast follow a polynomial decline and if a clear break could be observed between coastal and open sea waters, and at what distance to the shore.

\subsection{TSM concentrations for different sub basins}

The preliminary analysis using MERIS images showed that the concentration of total suspended matter varies somewhat in

5 the different sub-basin. In order to evaluate the concentrations for each sub basin particularly in the region of interest (area A and area B), the HELCOM classification and division of sub basins in the Baltic Sea was applied. This included both coastal and offshore water bodies. The interactive map is available at HECLOM map service and includes shapefiles and background information about how the sub-basins were defined (HELCOM Monitoring and Assessment Strategy, 2013).

The HELCOM sub-basin definition was further applied to the early June composite from 2011, where TSM values on the two regions of interest were extracted using vector shape files (Figure 5 and Figure 6).

\section{Results}

The resulting binned time-series of TSM concentrations (monthly means) during the summers 2009, 2010, 2011 are shown in (Figure 7).

\subsection{Excluding the influence of cyanobacteria occurrence}

15 The binned products (Figure 7) were evaluated with regards to terrestrial influence and the typical features caused by cyanobacteria blooms occurring typically during July-August (Hajdu et al., 1997; Kahru et al., 2007). The monthly composite from June 2011 (image 2011-06) in Figure 7 seemed least influenced by cyanobacteria blooms. However, Kahru and Elmgren (2014) found recently that the timing of surface accumulation of cyanobacteria in the Baltic Sea has shifted earlier in the season, by approximately an average rate of 0.6 days per year, causing the peak of the summer blooms to occur about 20 days earlier when compared to the start of the satellite measurements in 1979. In order to avoid the influence of cyanobacteria blooms in the TSM product, it was therefore decided to bin only images from the first part of June (Figure 8) and to use this composite for further analysis. This early June composite still shows the typical currents that are usually indicated by blooms of filamentous cyanobacteria. However, at this time of year, cyanobacteria blooms are unlikely to occur, and therefore it can be assumed that the image actually shows the distribution of coastal inorganic sediments, and therefore 25 can be used to assess the extent of coastal processes in the Baltic Sea basin.

In order to evaluate the distribution of phytoplankton in early June chlorophyll-a composite images for each year (20092011) were derived and compared to the TSM composites from early June (Figure 9). This comparison showed that the chl-a distribution in early June illustrates a different pattern when comparing to the TSM distribution, indicating a certain degree of de-coupling of the two parameters. It can therefore be assumed that the early June TSM composite does not represent the distribution of filamentous cyanobacteria, but instead indicates the distribution of inorganic sediments, and thus can be used 
Ocean Sci. Discuss., doi:10.5194/os-2016-2, 2016

Manuscript under review for journal Ocean Sci.

Published: 3 February 2016

(c) Author(s) 2016. CC-BY 3.0 License.

to evaluate the extent of coastal processes. The chl-a images show a phytoplankton bloom in the Bothnian Sea in 2010, which is most likely a late phytoplankton spring bloom. In the Baltic proper the chl-a concentrations are rather low (presumably indicating the occurrence of small flagellates), which is to be expected after the spring and before the onset of the summer bloom of filamentous cyanobacteria.

\section{$5 \quad 3.2$ Evaluating the extent of coastal processes in comparison to standard methods}

In order to evaluate how the SMHI-defined water body classification compares to the TSM concentration along the coast, the SMHI shape file 'Havsomr_y_2012_2' was overlaid on top of TSM composite image from early June 2011 (Figure 10 a), given that this composite had the best coverage for the Baltic Sea and was also composed of 3 images. Each pixel contained a value representing the average concentration of total suspended matter in $\mathrm{g} \mathrm{m}^{-3}$. The MERIS TSM composite from early

10 June 2011 overlaid with the shape file defining coastal zones according to SMHI shows that the coastal influence in reality reaches much further offshore in the eastern and southern areas of the Baltic Sea than both indicated by the SMHI water classification, and the 1 nautical mile line as defined by the EU WFD. The SMHI definition looks here rather arbitrary and fixed compared to the TSM distribution, but provides reference borders since the classification is based on physical criteria. The north-western and south-eastern parts of the Baltic Sea (Figure $10 \mathrm{~b}$ and 10c) were further analysed. Trend analysis was

15 performed in order to evaluate the behaviour of particles along a transect from coastal to offshore waters. During the analysis of the trendline it was found that most of transects were best described either by a logarithmic or a polynomial function. Thus, both functions were plotted on each figure, choosing the order of polynomial that scored the highest r-squared (Figure 11a).

The same analysis was applied to Bråviken; a bay situated about $50 \mathrm{~km}$ south-west of Himmerfjärden bay. Bråviken shows

20 much higher TSM concentrations and has a higher gradient of TSM, and the threshold was reached here at about $15 \mathrm{~km}$ offshore (about $50 \mathrm{~km}$ from Norrköping) for the polynomial function that showed the highest r-square value (Figure 11b).

Along the eastern, south-eastern and southern coasts, the trendlines were described best by either using a logarithmic function, or polynomial regression. Here, the threshold was reached much further off-shore, at about 34-52 km from the coast (Figures 11a - Figure 11b)

25 The values for TSM concentrations are slightly lower in the north-western basins of the Baltic proper (if not significantly influenced by cyanobacteria blooms), whereas in the eastern and southern basins concentrations are higher, presumably due to the higher input from large rivers in the southern Baltic (i.e. the Vistula and the Oder) and the sediment transport along the eastern coast up north due to the Coriolis force. The rivers bring in larger amounts of anthropogenic load from the densely populated areas in Poland and Germany. Higher concentrations of TSM in the water column may also be due to difference in

30 bottom type (less exposed rock than at the NW Swedish coast), and due to mud and sand kept in suspension by wind stirring and the dynamics of surface currents. Table 1 . summarizes the results of the trend analysis. 
Ocean Sci. Discuss., doi:10.5194/os-2016-2, 2016

Manuscript under review for journal Ocean Sci.

Published: 3 February 2016

(c) Author(s) 2016. CC-BY 3.0 License.

The monthly mean concentrations of TSM (June 2011) in all sub-basins of the Baltic Sea were extracted from MERIS data. The histograms of the composite images show means of TSM concentrations for the different Baltic Sea sub-basins are shown in Figure 12. The ranges of values and statistics for the different basins are shown in Table 2.

\section{Discussion}

5 The delineation of coastal waters using the water body classification by SMHI has shown to have only little agreement with the MERIS L3 binned TSM product for the Baltic Sea. In the NW Baltic, the TSM concentration reaches the local threshold of about $0.57 \mathrm{~g} \mathrm{~m}^{-3}$ between coastal and transitional waterbodies at a distance of approximately $15-27 \mathrm{~km}$ offshore. In the E, SE and S Baltic the situation is different. In the of those transects (E1, SE2, SE3, S4) we can observe that the TSM concentrations reaches the respective local thresholds ranging from 0.59 to $0.79 \mathrm{gm}^{-3}$ at a distance of approximately $34-52$

$10 \mathrm{~km}$ which is almost twice the distance compared to the north-western coast. The seabed in the southern Baltic is dominated by inorganic suspended matter (sand and clay), and the TSM particles extend much further into the open sea. In the NW Baltic Sea, the sea bottoms are dominated by exposed rock (Figure 13).

It was rather interesting to observe that the trend distribution of TSM particles along defined transects, in the E, SE and S Baltic Sea was not only best described by polynomial regression of the second order, as found by Kratzer and Tett (2009) for

15 north-western Baltic, but could be also well described by a logarithmic function. The highest coefficient of determination was used to identify which function had a better fit. The trend for both NW1 and NW2 were best described by a polynomial regression of $2^{\text {nd }}$ order with $r^{2}=0.84$ and $r^{2}=0.95$, respectively, implying that here diffusion is the dominant driver behind the particle distribution (Kratzer and Tett, 2009). As for the E, SE and S Baltic Sea the trend analysis was more complex, since other physical forces take place along this part of the Baltic Sea coast. Here, it can be assumed that wind-driven resuspension combined with the Coriolis effect are the main processes for distribution of TSM particles away from the coast, all the way into the open sea. In prior transect extraction from the composite of early June 2011, it was identified by Kyryliuk (2014) that the distribution of TSM particles along the transect in the south-eastern Baltic Sea using monthly composite from June 2011 could be described well by a logarithmic function, and overall had a better fit. However, our recent results from early June 2011 have shown that for the transects E1 and S4 the trend could be best described by a logarithmic function as assumed for the south-eastern coast. But transects SE2 and SE3 can also be described by a polynomial of second order, which is more typical for the north-western Baltic Sea. These differences could be caused by the high variability in coastal processes. For instance, a logarithmic trend may imply changes in the coastal dynamics (E1 and S4), whereas for SE2 and SE3 off-shore resuspension caused by eddies (fluid dynamics or two currents creating mesoscale features) may change the trendline from logarithmic to polynomial.

30 Essentially, the bio-optical model for north-western Baltic Sea (Kratzer and Tett, 2009) is based on a steady-state model that assumes a diffusional transport along the axis perpendicular of the coast. The mathematical solution comes from the use of a series of power functions that led to a comparison of simple polynomial models of various cases $\left(1^{\text {st }}, 2^{\text {nd }}, 3^{\text {rd }}\right)$, where the 
Ocean Sci. Discuss., doi:10.5194/os-2016-2, 2016

Manuscript under review for journal Ocean Sci.

Published: 3 February 2016

(c) Author(s) 2016. CC-BY 3.0 License.

transport of particles is moving from the source (land, river outlet, sewage treatment plant; high end member) towards the open sea (sink or low end member). Here, low order polynomials denote various biological and chemical processes within a given gradient. Kratzer and Tett (2009) found that SPM (conservative substance) was best described by a second order polynomial, CDOM by third order polynomial and chl-a by a linear function. As for the south-eastern Baltic, it is possible to

5 derive a steady-state exponential regression model based on the assumption that (1) there is a coastal source and an off-shore sink; (2) that the transport distance of SPM that moved offshore is a linear function of time elapsed since a packet of water left the source; (3) that the regression rate is constant. However, at the south-eastern coast of the Baltic Sea a logarithmic function showed a better fit, indicating different dynamical processes. Another explanation why TSM is carried further offshore in this region may be found in the bottom topography of the Baltic Sea. The SE Baltic is rather shallow and slopes rather smoothly, which has an effect on the extent of physical processes such as coastal upwelling (Myberg and Andrejev, 2003 ) and the development of internal waves. The SE Baltic Sea is also more exposed to wind (Danielsson et al., 2007), which combined with the sandy and muddy bottom substrates, enhances the dynamics and the resuspension of sediments, and the transport of particles further offshore.

The NW Baltic is less exposed to wind and therefore diffusion may be assumed here to be the main driving force for the distribution of matter as assumed and tested in Kratzer and Tett (2009). Furthermore, in the NW Baltic proper, the bottom depth increases within a relatively short distances from the shore. i.e. coastal morphology is much steeper (Figure 15). The deepest part of the Baltic Sea is at Landsort Deep (459 m depth), which is only about $30 \mathrm{~km}$ offshore. The bottom topography is also characterised by a great number of sills, separating different sub-basins (Figure 15 NW1). These factors combined may lead to the settling and falling out of suspended matter closer to the shore, i.e. the sills interrupting the different basins may prevent exchange with the open sea water, and the internal circulation in each basin may facilitate the settling out of heavier particles closer to the shore.

The water depth (m) values of the transect NW1 through Himmerfjärden bay and out to Landsort deep were plotted against the distance from the shore (in $\mathrm{km}$ ). This depth profile was then compared to the TSM values extracted along the same transect. The depth profile was obtained from The Baltic Sea bathymetry by HELCOM and IOW (maps.helcom.fi). The

25 shoreline slopes are quite deep and erratic in the Himmerfärden area (Figure 15). Himmerfjärden consists of a series of basins that are separated by sills. The depth profile in Bråviken (NW2) shows a different trend. The water depth remains rather shallow when moving away from the inner bay which is also interrupted by sills. The increase in depth becomes obvious at 40-45 km, at the geographical 'end' of Bråviken. Here, the TSM concentrations drop rapidly and tend towards local threshold $\left(0.57 \mathrm{~g} \mathrm{~m}^{-3}\right)$ at approximately the same distance as the sudden increase in depth. The threshold is reached at a depth of about 15-20 meters. The eastern transect (E1) at the Latvian coast shows yet another depth profile. Here, the shoreline slopes quite smoothly when compared to NW1 and NW2, without any intermittent sills. The slope is rather steep in the first $10 \mathrm{~km}$ with a brief transition to lower depths and then the depth drops suddenly between $25 \mathrm{~km}$ (at $15 \mathrm{~m}$ depth) to 50 $\mathrm{km}$ (at $90 \mathrm{~m}$ depth). This increase can be described as gradual, but relatively steep. The observed TSM values follow the depth profile closely to up about $10 \mathrm{~km}$ distance from the shore, after which no clear pattern of co-dependence is detected. 
Ocean Sci. Discuss., doi:10.5194/os-2016-2, 2016

Manuscript under review for journal Ocean Sci.

Published: 3 February 2016

(c) Author(s) 2016. CC-BY 3.0 License.

The SE2 depth profile is steep but gradual, without any recurring intermittent sills. The TSM values along the transect nearly repeat the pattern of the depth profile starting to decline at about $10 \mathrm{~km}$ from the shore. For the SE3 profile the increase in depth is linear and rather steep, again, with no interrupting sills but with a few ridges. The TSM values drop here suddenly within the first $5 \mathrm{~km}$ where the depth also drops from 0 to $20 \mathrm{~m}$. Further at about $10 \mathrm{~km}$ distance the TSM concentration gets

5 higher and then drops again, tending towards the local threshold and following a polynomial trend as the depth increases again. The southern transect (S4, Gulf of Gdansk) the TSM concentration drops suddenly at about $10 \mathrm{~km}$ off the shore, where the depth also decreases to $60 \mathrm{~m}$. Thus, both the SPM concentration and the depth profile show a similar trend. After $15 \mathrm{~km}$ the bottom inclination becomes more gradual. The TSM values show a logarithmic trend along the chosen transect. Physical forces such as diffusion, wind, resuspension - and more importantly - bottom profile and the nature of the bottom

10 substrates may thus play a significant role in distribution of total suspended matter in coastal regions. Similar sediment dynamics were observed by Tang et al. (2013) on the Beaufort Shelf, which is influenced by the Mackenzie River run-off, wind direction and the surface circulation. The authors analysed the dispersion pattern of the Mackenzie River plume near the mouth of the estuary, using algorithms for two highly contrasting run-off scenarios. The first scenario included a similar wind forcing strength when river run-off was low. Here, the sediment plumes tended to spread less further offshore and with lower TSM concentrations within the plumes. The second scenario was linked with higher river run-off, where the entire coastal area was subsequently loaded with very high TSM concentrations, leading to an occurrence of extensive offshore plumes. Tang et al. (2013) concluded that remote sensing can indicate important aspects about the dispersal pattern of TSM plumes, and the distribution of suspended matter in coastal ecosystems.

Mulligan et al. (2010) observed that not only river run-off can lead to rather different plume distribution patterns, but also wind direction and physical forcing. A combination of locally-derived optical algorithms for deriving TSM from remote sensing data allows for a rather comprehensive overview of coastal dynamics in relation to environmental forcing. Increased precipitation leads to increased land run-off and fluxes of sediment loads to the sea (Miller and McKee, 2004), and TSM generally acts an indicator for coastal run-off and wind forcing (Kratzer and Tett, 2009).

An increase of land run-off has been predicted for Northern Scandinavia with the advance of climate change. Time series of 25 remote sensing data can be used to evaluate changes in the distribution of suspended matter in coastal areas, which are most affected by river discharges in the vicinity of urban areas. The algorithms developed for regional applications play a significant role in acquiring reliable measurements from satellite images. Further research requires the use of more accurate regional algorithms for TSM retrieval as well as adapting hydrological models to be able to estimate water exchange with the coast and how climate and certain weather conditions e.g. wind direction and precipitation can affect concentration of suspended particles. 
Ocean Sci. Discuss., doi:10.5194/os-2016-2, 2016

Manuscript under review for journal Ocean Sci.

Published: 3 February 2016

(c) Author(s) 2016. CC-BY 3.0 License.

\section{Conclusions}

This work demonstrates that ocean colour remote sensing can provide important information for Baltic Sea research and management e.g. from the investigation of river discharge and phytoplankton blooms to the monitoring of coastal processes. The main advantages of marine remote sensing methods are synoptic large-scale coverage of the entire Baltic Sea (Figure 6-

5 11) with good spatial and temporal resolution (Kratzer et al., 2014; Harvey et al., 2015).

From a management perspective it is rather crucial to understand how ecosystem state varies over time and space and to have a synoptic overview of these changes. MERIS images as shown in Figure 8 allow for the monitoring of diffuse as well as point sources, such as a sewage treatment plant. This is important, as usually only the big streams are monitored by the Swedish river and coastal monitoring programs (SLU database).

10 TSM has shown to be a good indicator for ecosystem state, as it both indicates terrestrial run-off as well as wind-driven resuspension of particles, which is typical for coastal processes. Monthly mean estimates of TSM load for the different Baltic Sea basins can be used for evaluating seasonal fluctuations in those physical drivers. This is important complementary data for the monthly means of chlorophyll, which are used, both in the HELCOM periodic assessments as well as for the definition of water quality status according to the WFD. Turbidity (caused by SPM) is one of the mandatory parameters

15 listed in the EU's Marine Strategy Framework Directive (Annex III, EC, 2008). Thus, including remote sensing in management allows for a more comprehensive analysis of system drivers and the productive status of the marine ecosystem. In this paper we used local thresholds between coastal and offshore waters ranging from $0.57-0.79 \mathrm{mg} \mathrm{m}^{-1}$, based on the statistical analysis of MERIS data and the HELCOM division of sub-basins. The results indicate that the coastal zone extends substantially farther than shown by the water body classification by SMHI.

20 Here, satellite-derived TSM has shown to be an alternative tool for describing the fluctuations and changes in the extent of coastal processes. Strictly speaking, the extent of coastal waters is not a fixed line in relation to the distance from shore but it varies with seasonal variations of terrestrial run-off and local weather and/or climate conditions, such as sudden storm events as well as general high wind exposure as in the SW Baltic proper, where there is also a high fluvial input. More work has to be done to evaluate the seasonal fluctuations of the coastal zone, and also to evaluate the uncertainties in the method.

25 TSM can be derived with rather high accuracy from MERIS data (Kratzer and Vinterhav, 2010; Beltran et al., 2014), and may therefore be advantageous in comparison to a model that is based on many input variables, such as the hydrological model developed by SMHI. Each variable has its own error attached to it, and all errors add up to the total error. It is also known from methods in ecology that the more a complicated method, the higher the uncertainties inherent in the method (Peters, 1991).

30 Furthermore, the water-exchange model developed for SMHI was initially developed on hydro-geophysical parameters in Himmerfjärden (Engqvist 1996), and was then later applied to the whole Swedish coastline. However, the hydrological schemes and sediment transport into the different catchments may differ, as shown in this paper, causing regional errors. 
Ocean Sci. Discuss., doi:10.5194/os-2016-2, 2016

Manuscript under review for journal Ocean Sci.

Published: 3 February 2016

(c) Author(s) 2016. CC-BY 3.0 License.

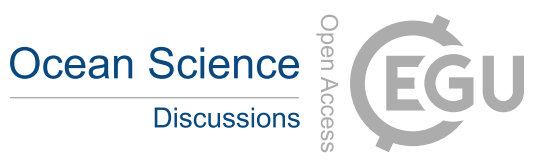

(c) (i)

Therefore, we would like to recommend the use of satellite data in models defining the extent of the coastal zones, both on national and international scale. This would be highly relevant from a management perspective. MERIS was operational between 2002-2012, so there is a substantial data set to also evaluate inter-annual variability of seasonal run-off. The MERIS mission is planned to be continued by OLCI on Sentinel-3, which is planned to be launched by ESA in autumn 2015.

5 Acknowledgements

This research was funded by Swedish National Space Board and European Space Agency. The satellite imagery and detailed information on data processing was provided by Dr. Petra Phillipson, Brockmann Geomatics, Sweden AB. Thanks to Brockmann Cosult, Germany for data processing. Thanks to Kari Eilola from SMHI for comments to a previous version of this manuscript. 
Ocean Sci. Discuss., doi:10.5194/os-2016-2, 2016

Manuscript under review for journal Ocean Sci.

Published: 3 February 2016

(c) Author(s) 2016. CC-BY 3.0 License.

\section{References}

Attila, J., Koponen, S., Kallio, K., Lindfors, A., Kaitala, S. and Ylöstalo, P.: MERIS Case II water processor comparison on coastal sites of the northern Baltic Sea, Remote Sensing of Environment, 128, 138-149, doi:10.1016/j.rse.2012.07.009, 2013.

5 Beltran-Abaunza, J. M., Kratzer, S. and Brockmann, C.: Evaluation of MERIS products from Baltic Sea coastal waters rich in CDOM, Ocean Science, 10(3), 377-396, doi:10.5194/os-10-377-2014, 2014.

Cederwall, H. and Elmgren R.: Biological effects of eutrophication in the Baltic Sea, particularly the coastal zone. Ambio, 19.3: 109-112, 1990.

Danielsson, Å., Jönsson, A. and Rahm, L.: Resuspension patterns in the Baltic proper, Journal of Sea Research, 57(4), 25710 269, doi:10.1016/j.seares.2006.07.005, 2007.

Delwart, S., Preusker, R., Bourg, L., Santer, R., Ramon, D. and Fischer, J.: MERIS in-flight spectral calibration, International Journal of Remote Sensing, 28:3-4, 479-496, DOI: 10.1080/01431160600821119, 2007.

Directive 2008:56:EC of the European Parliament and of the Council of 17 June 2008 establishing a framework for community action in the field of marine environmental policy (Marine Strategy Framework Directive),1-22, 2008.

15 Doerffer, R. and Schiller, H.: The MERIS case 2 water algorithm, International Journal of Remote Sensing, 28(3-4), 517535, doi:10.1080/01431160600821127, 2007.

Doerffer, R. and Schiller, H.: MERIS lake water algorithm for BEAM ATBD, GKSS Research Center, Geesthacht, Germany. Version 1.0, 10 June 2008.

Doerffer, R. and Schiller, H.: MERIS regional, coastal and lake case 2 water project - Atmospheric Correction ATBD. GKSS Research Center, Geesthacht, Germany. Version 1.0, 18 May 2008.

EC European Commission. Directive 2008/56/EC of the European Parliament and of the Council of 17 June 2008 establishing a framework for Community action in the field of marine environmental policy (Marine Strategy Framework Directive). Official Journal of the European Communities L164/19 25.06.2008; 2008.

European Communities: Water Framework Directive, Directive 2000/60/EC of the European Parliament and of the Council

25 of 23 October 2000 establishing a framework for Community action the in the field of water policy, Official Journal of the European Comminities L 327: 1-73, 2000.

Engqvist, A.: Long-term nutrient balances in the eutrophication of the Himmerfjarden estuary, Estuarine Coastal and Shelf Science, 42(4), 483-507, doi:10.1006/ecss.1996.0031, 1996.

Hajdu, S., Larsson, U. and Skärlund, K.: "Växtplankton.[Phytoplankton]." Himmerfjärden. Förändringar i ett näringsbelastat

30 kustekosystem i Östersjön.[Himmerfjärden. Changes in a nutrientenriched coastal ecosystem of the Baltic Sea]. Naturvårdsverket (SEPA). Report 4565: 63-79, 1997. 
Ocean Sci. Discuss., doi:10.5194/os-2016-2, 2016

Manuscript under review for journal Ocean Sci.

Published: 3 February 2016

(c) Author(s) 2016. CC-BY 3.0 License.

Harvey, E. T., Kratzer, S. and Philipson, P.: Satellite-based water quality monitoring for improved spatial and temporal retrieval of chlorophyll-a in coastal waters, Remote Sensing of Environment, 158, 417-430, doi:10.1016/j.rse.2014.11.017, 2015.

Helsinki Comission: HELCOM Draft Monitoring and Assessment Strategy, 1-30, 2013.

5 Helsinki Commission: HELCOM Baltic Sea Action Plan, vol. 15, pp. 899-917, HELCOM Ministerial Meeting. Krakow, 2007.

Isemer, H. -J. and Rozwadowska, A.: Solar radiation fluxes at the surface of the Baltic proper, Part 2: Uncertainties and comparison with simple bulk parameterizations. Oceanologia, 41: 147-185, 1999.

Kahru, M. and Elmgren, R.: Multidecadal time series of satellite-detected accumulations of cyanobacteria in the Baltic Sea,

10 Biogeosciences, 11(13), 3619-3633, doi:10.5194/bg-11-3619-2014, 2014.

Kahru, M., Savchuk, O. P. and Elmgren, R.: Satellite measurements of cyanobacterial bloom frequency in the Baltic Sea: interannual and spatial variability, Mar. Ecol. Prog. Ser., 343, 15-23, doi:10.3354/meps06943, 2007.

Karlsson, K.-G. R.: A 10 year cloud climatology over Scandinavia derived from NOAA Advanced Very High Resolution Radiometer imagery, International Journal of Climatology, 23(9), 1023-1044, doi:10.1002/joc.916, 2003.

15 Kopenen, S., Ruiz-Verdú, A., Heege, T., Heblinski, J., Sorensen, K., Kallio, K., Pyhälahti T., Doerffer, R., Brockmann, C. and Peters, M.: Development of MERIS lake water algorithms, Validation Report, 2008.

Kratzer, S. and Tett, P.: Using bio-optics to investigate the extent of coastal waters: A Swedish case study, Hydrobiologia, 629(1), 169-186, doi:10.1007/s10750-009-9769-x, 2009.

Kratzer, S. and Vinterhav, C.: Improvement of MERIS level 2 products in Baltic Sea coastal areas by applying the Improved

20 Contrast between Ocean and Land processor (ICOL) - data analysis and validation, OCEANOLOGIA, 52(2), 211-236, doi:10.5697/oc.52-2.211, 2010.

Kratzer, S., Brockmann, C. and Moore, G.: Using MERIS full resolution data to monitor coastal waters - A case study from Himmerfjärden, a fjord-like bay in the northwestern Baltic Sea, Remote Sensing of Environment, 112(5), 2284-2300, doi:10.1016/j.rse.2007.10.006, 2008.

25 Kratzer, S., Ebert, K. and Sørensen, K.: Monitoring the Bio-optical State of the Baltic Sea Ecosystem with Remote Sensing and Autonomous In Situ Techniques, in The Baltic Sea Basin, pp. 407-435, Springer Berlin Heidelberg, Berlin, Heidelberg. 2011.

Kratzer, S., Therese Harvey, E. and Philipson, P.: The use of ocean color remote sensing in integrated coastal zone management-A case study from Himmerfjärden, Sweden, Marine Policy, 43, 29-39, doi:10.1016/j.marpol.2013.03.023, 2014.

Kyryliuk, D.: Total suspended matter derived form MERIS data as an indicator of coastal processes in the Baltic Sea, Master's thesis, Department of Ecology, Environment and Plant Sciences, Stockholm University, 2014.

Leppäranta, M., Myberg, K.: Physical Ocenography of the Baltic Sea, 2009. 
Ocean Sci. Discuss., doi:10.5194/os-2016-2, 2016

Manuscript under review for journal Ocean Sci.

Published: 3 February 2016

(c) Author(s) 2016. CC-BY 3.0 License.

Lessin, G. and Raudsepp, U.: Modelling the spatial distribution of phytoplankton and inorganic nitrogen in Narva Bay, southeastern Gulf of Finland, in the biologically active period, Ecological Modelling, 201(3-4), 348-358, doi:10.1016/j.ecolmodel.2006.09.025, 2007.

Miller, R. L. and McKee, B. A.: Using MODIS Terra $250 \mathrm{~m}$ imagery to map concentrations of total suspended matter in

5 coastal waters, Remote Sensing of Environment, 93(1-2), 259-266, doi:10.1016/j.rse.2004.07.012, 2004.

Mueller, J. L. and Austin, R. W., Eds.: Ocean Optics Protocols for SeaWiFS Validation, Revision 1. NASA Technical Memorandum 104566. Maryland, Goodard Space Flight Centre, 1995.

Mulligan, R. P., Perrie, W. and Solomon, S.: Dynamics of the Mackenzie River plume on the inner Beaufort shelf during an open water period in summer, Estuarine, Coastal and Shelf Science, 89(3), 214-220, doi:10.1016/j.ecss.2010.06.010, 2010.

10 Myrberg, K. and Andrejev, O.: Main upwelling regions in the Baltic Sea - a statistical analysis based on three-dimensional modelling, Boreal Environment Research, 8(2), 97-112, 2003.

Naturvårdsverket: Naturvårdsverkets författningssamling, NFS 2006:1, 1-19, 2006.

Peters, R., H.: A critique for ecology. Cambridge University Press, 1991.

Philipson, P., Kratzer, S., Ben Mustapha, S., Strömbeck, N. and Stelzer, K.: Satellite-based water quality monitoring in Lake

15 Vänern, Sweden, submitted to International Journal of Remote Sensing, Dec 2015.

Ruiz-Verdú, A., Koponen, S., Heege, T., Doerffer, R., Brockmann, C., Kallio, K. and Ylöstalo, P.: Development of MERIS lake water algorithms: Validation results from Europe. In: Proceedings of the 2nd MERIS/(A) ATSR user workshop. Frascati, Italy, 2008.

Santer, R. and Zagolski, F.: ICOL - Improve Contrast between Ocean and Land, ATBD (Algorithm Theoretical Basis Document) - MERIS Level-1C, Version 1.1, 6 January 2009. Université du Littoral Côte d'Opale, Wimereux, France. Report D6:1-15, 2009.

Schiller, H. and Doerffer, R.: Neural network for emulation of an inverse model - operational derivation of Case II water properties from MERIS data, International Journal of Remote Sensing, 20(9), 1735-1746, doi:10.1080/014311699212443, 1999.

25 Schroeder, T., Behnert, I., Schaale, M., Fischer, J. and Doerffer, R.: Atmospheric correction algorithm for MERIS above case-2 waters, International Journal of Remote Sensing, 28(7), 1469-1486, doi:10.1080/01431160600962574, 2007.

Schroeder, T., Schaale, M. and Fischer, J.: Retrieval of atmospheric and oceanic properties from MERIS measurements: A new Case-2 water processor for BEAM, 28(24), 5627-5632, doi:10.1080/01431160701601774, 2007.

Strickland, J. H. D. and Parsons, T. R.: A practical handbook of sea-water analysis. Bulletin Journal of the Fisheries

Research Board of Canada, 167: 185-203, 1972.

Tang, S., Larouche, P., Niemi, A. and Michel, C.: Regional algorithms for remote-sensing estimates of total suspended matter in the Beaufort Sea, International Journal of Remote Sensing, 34(19), 6562-6576, doi:10.1080/01431161.2013.804222, 2013. 
Ocean Sci. Discuss., doi:10.5194/os-2016-2, 2016

Manuscript under review for journal Ocean Sci.

Published: 3 February 2016

(c) Author(s) 2016. CC-BY 3.0 License.

\begin{tabular}{|c|c|c|c|}
\hline Transect & Function & Trendline fit & $r^{2}$ \\
\hline NW1 & Polynomial $2^{\text {nd }}$ & $y=0.000196 x^{2}-0.0223 x+1.219$ & 0.84 \\
\hline NW1 & Logarithmic & $y=-0.194 \ln (x)+1.38$ & 0.82 \\
\hline NW2 & Polynomial $2^{\text {nd }}$ & $y=0.00193 x^{2}-0.232 x+7.391$ & 0.95 \\
\hline NW2 & Logarithmic & $y=-1.91 \ln (x)+8.66$ & 0.81 \\
\hline E1 & Polynomial $2^{\text {nd }}$ & $y=0.00037 x^{2}-0.0318 x+1.217$ & 0.46 \\
\hline E1 & Logarithmic & $y=-0.255 \ln (x)+1.49$ & 0.64 \\
\hline SE2 & Polynomial $2^{\text {nd }}$ & $y=9.21 \mathrm{e}-0.5 x^{2}-0.0192 x+1.346$ & 0.84 \\
\hline SE2 & Logarithmic & $y=-0.254 \ln (x)+1.65$ & 0.75 \\
\hline SE3 & Polynomial $2^{\text {nd }}$ & $y=0.000577 x^{2}-0.048 x+1.589$ & 0.77 \\
\hline SE3 & Logarithmic & $y=-0.306 \ln (x)+1.78$ & 0.84 \\
\hline S4 & Polynomial $2^{\text {nd }}$ & $y=0.00084 x^{2}-0.0867 x+2.804$ & 0.52 \\
\hline S4 & Logarithmic & $y=-0.76 \ln (x)+3.65$ & 0.72 \\
\hline
\end{tabular}

The highest coefficient of determination $\left(r^{2}\right)$ was chosen and used to identify the best fit of a function (bold) 
Ocean Sci. Discuss., doi:10.5194/os-2016-2, 2016

Manuscript under review for journal Ocean Sci.

Published: 3 February 2016

(c) Author(s) 2016. CC-BY 3.0 License.

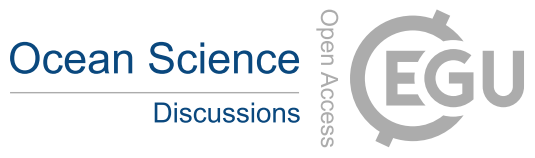

(c) ${ }_{\mathrm{By}}$

\begin{tabular}{llllll}
\multicolumn{7}{l}{ Table 2. Min, Max, Mean and Median values for the different basins. } \\
\hline Basin: & Minimum: & Maximum: & Mean: & Median: & Unit: \\
\hline Bothnian Sea & 0.14 & 24.10 & 0.61 & 0.55 & $\mathrm{~g} \mathrm{~m}^{-3}$ \\
Bothnian Bay & 0.18 & 39.96 & 0.64 & 0.50 & $\mathrm{~g} \mathrm{~m}^{-3}$ \\
Gulf of Riga & 0.30 & 41.23 & 1.58 & 0.96 & $\mathrm{~g} \mathrm{~m}^{-3}$ \\
Eastern Gotland Basin & 0.27 & 39.10 & 0.72 & 0.62 & $\mathrm{~g} \mathrm{~m}^{-3}$ \\
Western Gotland Basin & 0.11 & 40.20 & 0.52 & 0.49 & $\mathrm{~g} \mathrm{~m}^{-3}$ \\
Gulf of Gdansk & 0.57 & 29.15 & 2.59 & 0.94 & $\mathrm{~g} \mathrm{~m}^{-3}$ \\
Southern Baltic Sea & 0.10 & 49.99 & 1.07 & 0.55 & $\mathrm{~g} \mathrm{~m}^{-3}$ \\
Kattegat & 0.12 & 49.44 & 0.95 & 0.50 & $\mathrm{~g} \mathrm{~m}^{-3}$ \\
Kiel Bay & 0.14 & 31.61 & 0.44 & 0.33 & $\mathrm{~g} \mathrm{~m}^{-3}$ \\
Bay of Mecklenburg & 0.18 & 36.11 & 0.69 & 0.45 & $\mathrm{~g} \mathrm{~m}^{-3}$ \\
The Sound & 0.12 & 49.12 & 1.11 & 0.36 & $\mathrm{~g} \mathrm{~m}^{-3}$ \\
Little Belt & 0.13 & 45.02 & 0.91 & 0.43 & $\mathrm{~g} \mathrm{~m}^{-3}$ \\
Great Belt & 46.33 & 1.04 & 0.44 & $\mathrm{~g} \mathrm{~m}^{-3}$ \\
Northern Baltic Proper & 0.11 & 48.94 & 0.68 & 0.55 & $\mathrm{~g} \mathrm{~m}^{-3}$ \\
Gulf of Finland & 0.17 & 34.16 & 1.05 & 0.85 & $\mathrm{~g} \mathrm{~m}^{-3}$ \\
Aland Sea & 0.15 & 20.62 & 0.59 & 0.56 & $\mathrm{~g} \mathrm{~m}^{-3}$ \\
Archipelago Sea & 0.07 & 26.62 & 1.04 & 0.76 & $\mathrm{~g} \mathrm{~m}^{-3}$ \\
The Quark & 0.17 & 14.94 & 0.63 & 0.55 & $\mathrm{~g} \mathrm{~m}^{-3}$ \\
Skagerrak & 0.13 & 33.98 & 0.46 & 0.40 & $\mathrm{~g} \mathrm{~m}^{-3}$ \\
\hline
\end{tabular}


Ocean Sci. Discuss., doi:10.5194/os-2016-2, 2016

Manuscript under review for journal Ocean Sci.

Published: 3 February 2016

(c) Author(s) 2016. CC-BY 3.0 License.
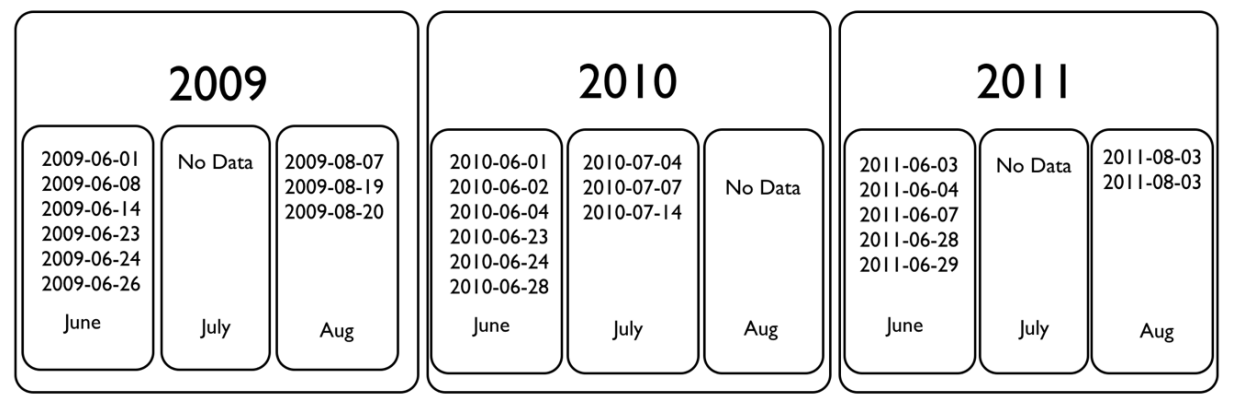

Figure 1. Diagram summarizing the binning procedure using BEAM. All viable scenes in a month were binned to a monthly product. Bins containing the comment 'No Data' do not necessarily imply unavailability of data, but may imply scenes with high cloud cover, and as a result with low numbers of valid pixels. Scenes with very high cloud coverage were thus not further binned 5 into monthly averaged images, as these would not have been representative.

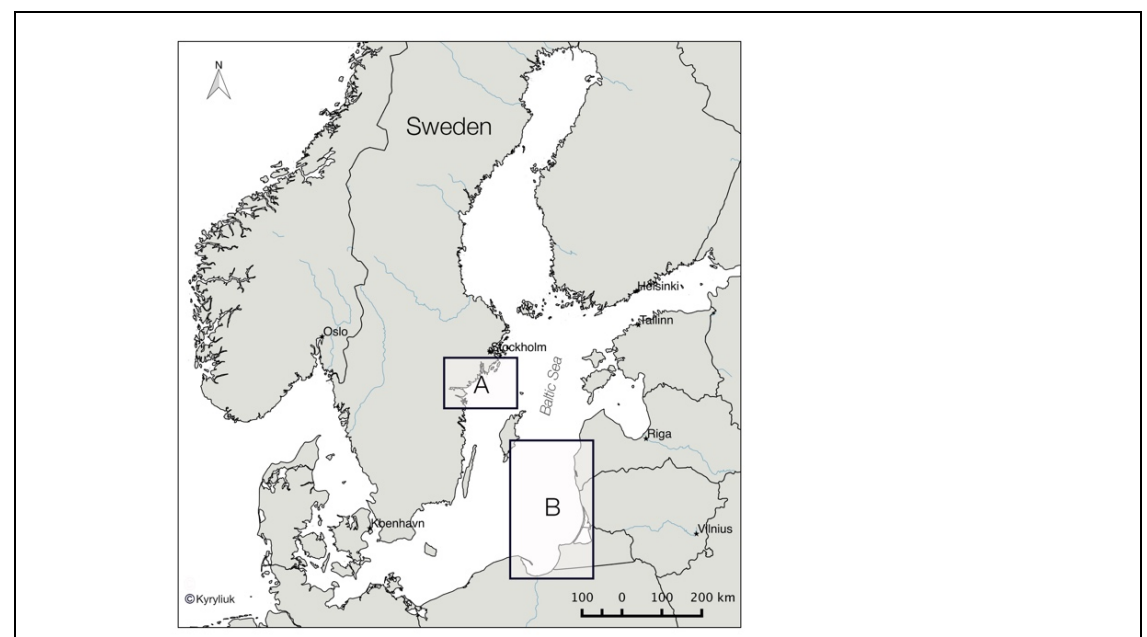

Figure 2. Overview map of Swedish coastal areas in the North-western Baltic Proper and Lithuanian and Polish coastal waters in the south-eastern and southern Baltic Proper. The map was created using the open source software QGIS. 
Ocean Sci. Discuss., doi:10.5194/os-2016-2, 2016

Manuscript under review for journal Ocean Sci.

Published: 3 February 2016

(c) Author(s) 2016. CC-BY 3.0 License.

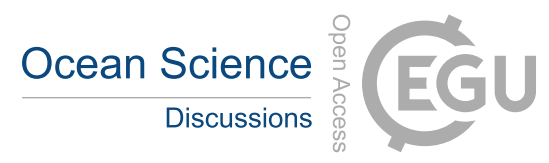

(c) (i)

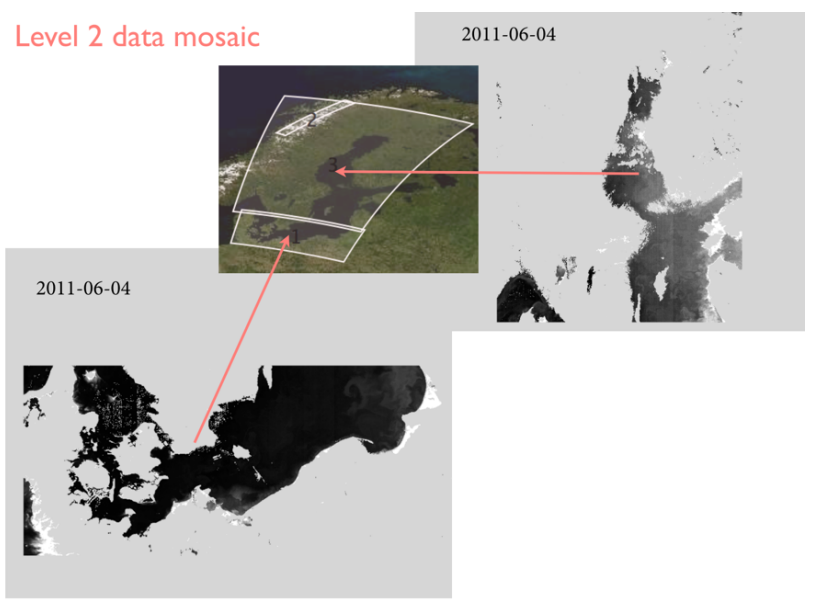

Figure 3. Using the mosaic function to derive images covering the Baltic Sea basin BEAM v. 4.11

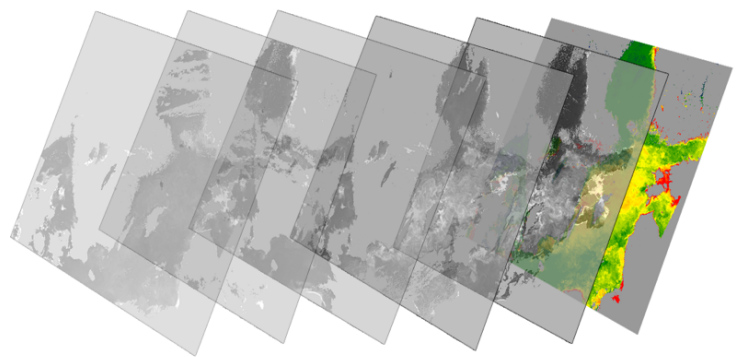

5 Figure 4. Visualization of L3 Binning process. Images of each available day are binned together to produce a final image with average TSM concentrations for each months of the year. 
Ocean Sci. Discuss., doi:10.5194/os-2016-2, 2016

Manuscript under review for journal Ocean Sci.

Published: 3 February 2016

(c) Author(s) 2016. CC-BY 3.0 License.
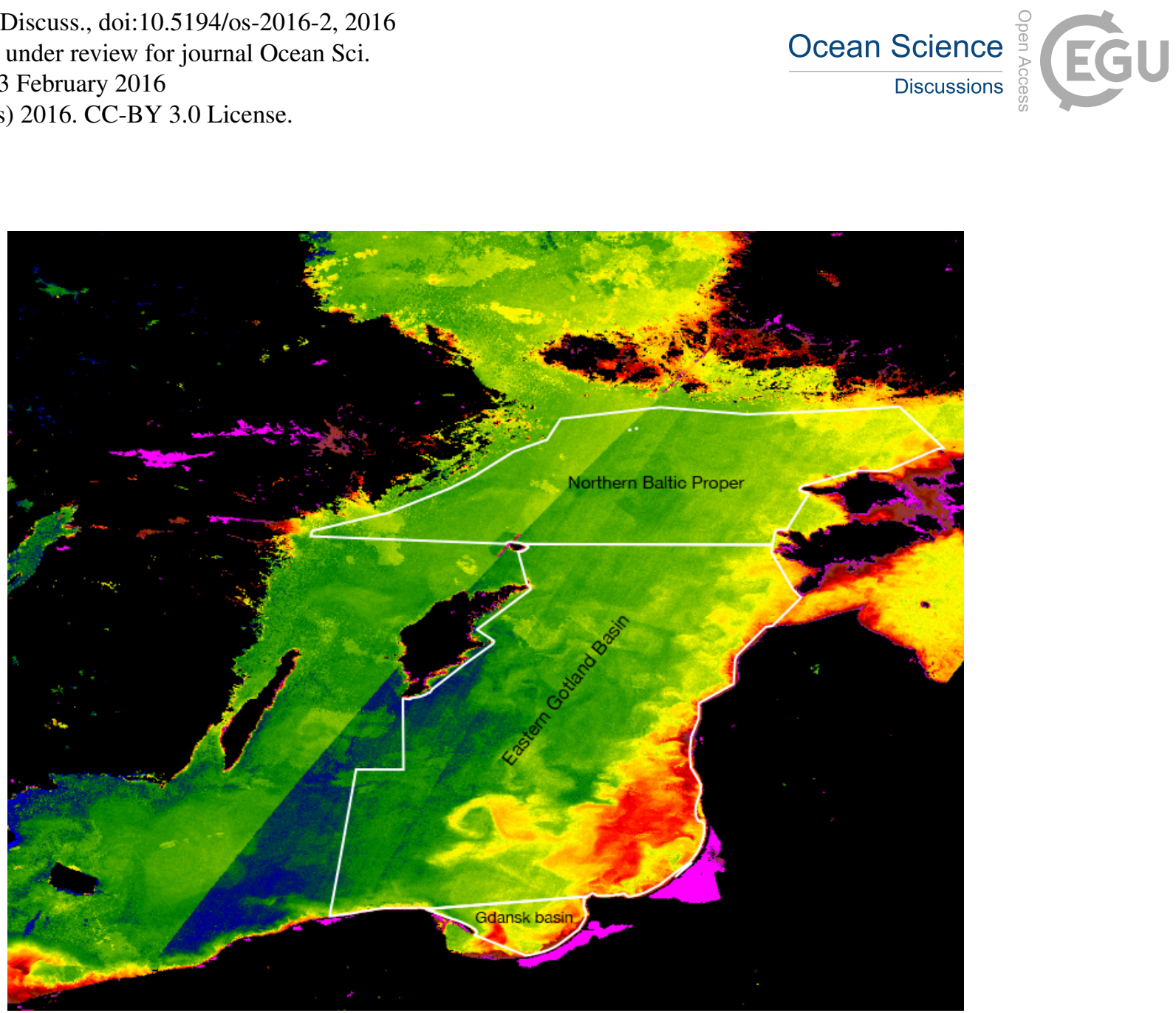

Figure 5. Early June composite from 2011 with the Northern Baltic Proper, the Eastern Gotland Basin and the Gulf of Gdansk (vector shapes from HELCOM sub-basin division map). Please note that the striping is caused by MERIS camera 4 (western side of the swath); camera 4 is known to give different readings to the other cameras (Delwart, et al., 2007). 
Ocean Sci. Discuss., doi:10.5194/os-2016-2, 2016

Manuscript under review for journal Ocean Sci.

Published: 3 February 2016

(c) Author(s) 2016. CC-BY 3.0 License.

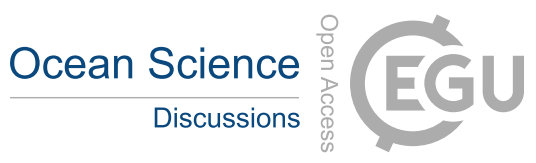

(c) (i)
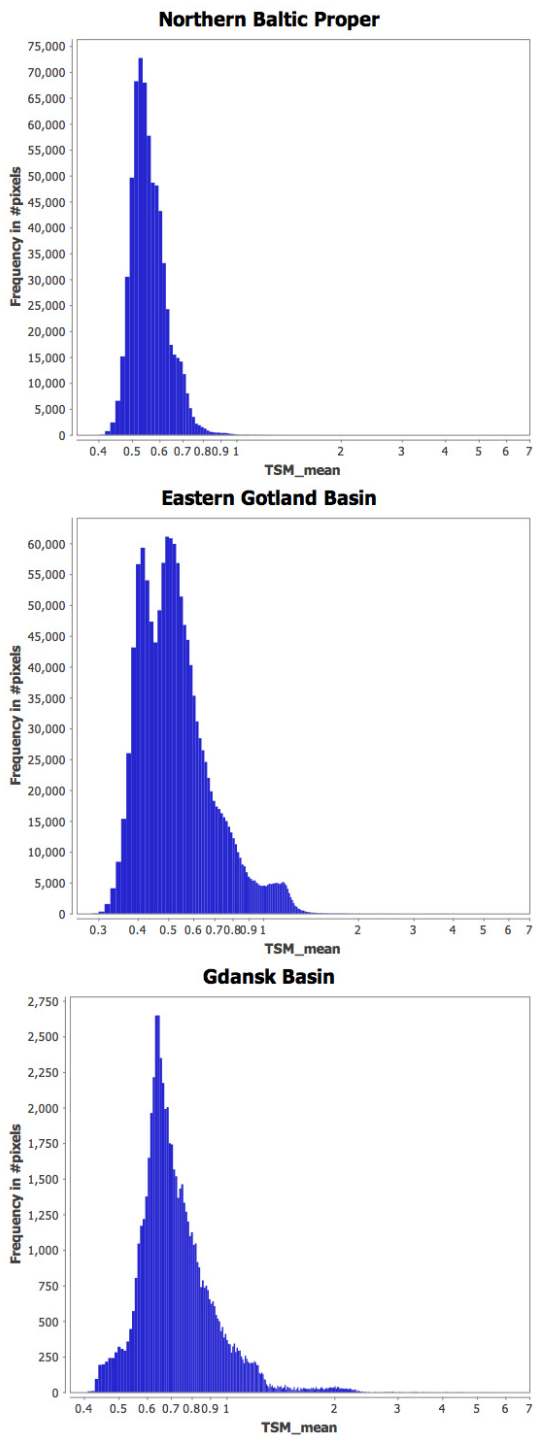

Figure 6. TSM values extracted using HELCOM shapefiles presented via histograms. Open sea values were identified visually for each basin and be evaluating of peak and intersections between populations of values (i.e. coastal vs. open sea values): Northern Baltic Sea $\left(0.57 \mathrm{~g} \mathrm{~m}^{-3}\right)$; Eastern Gotland Basin $\left(0.59 \mathrm{~g} \mathrm{~m}^{-3}\right)$; Gulf of Gdansk $\left(0.79 \mathrm{~g} \mathrm{~m}^{-3}\right)$. 
Ocean Sci. Discuss., doi:10.5194/os-2016-2, 2016

Manuscript under review for journal Ocean Sci.

Published: 3 February 2016

(c) Author(s) 2016. CC-BY 3.0 License.

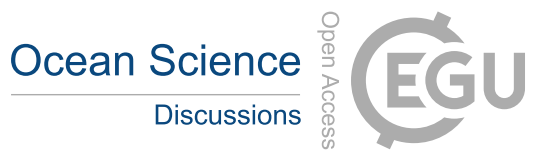

(c)

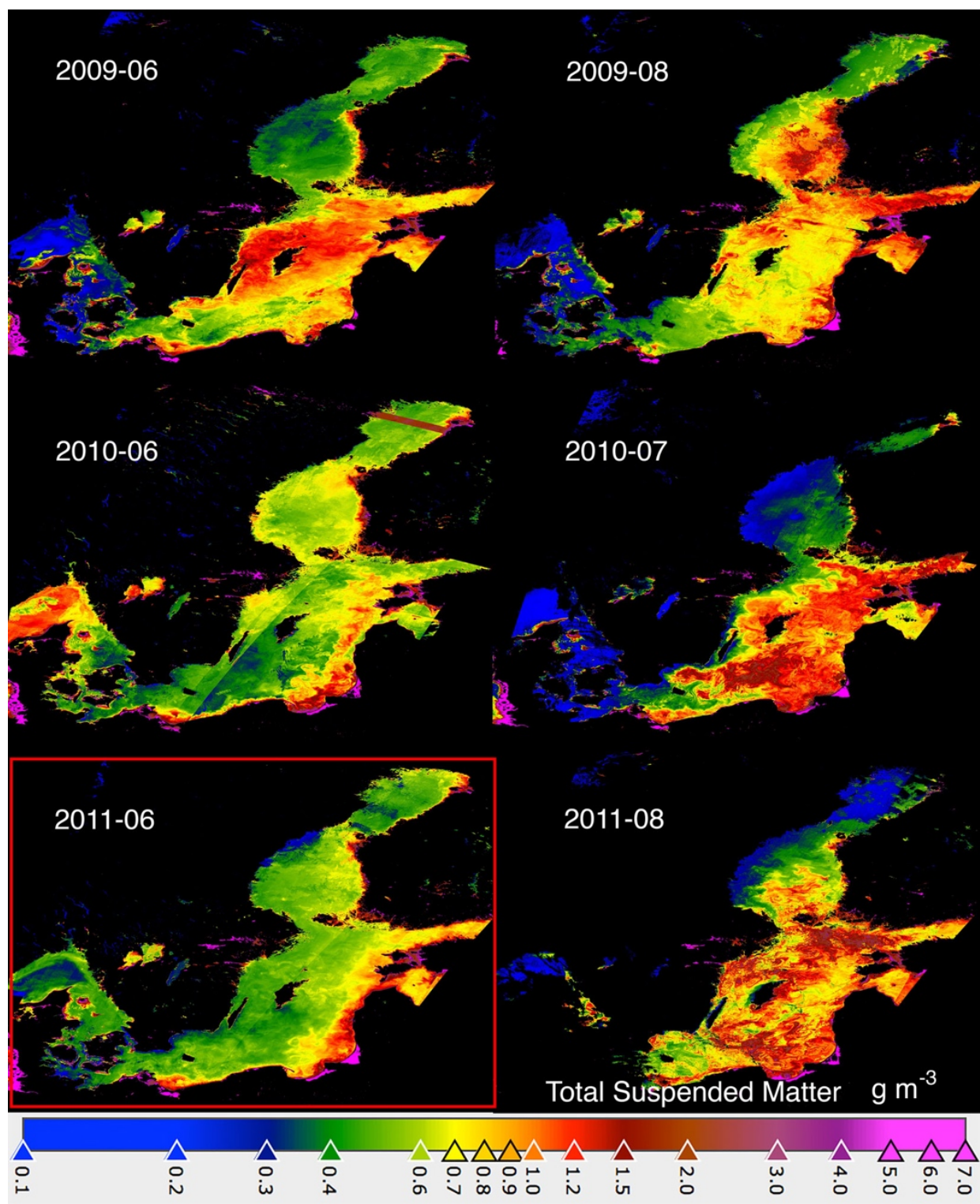

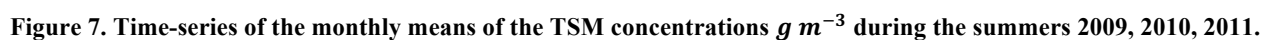


Ocean Sci. Discuss., doi:10.5194/os-2016-2, 2016

Manuscript under review for journal Ocean Sci.

Published: 3 February 2016

(c) Author(s) 2016. CC-BY 3.0 License.

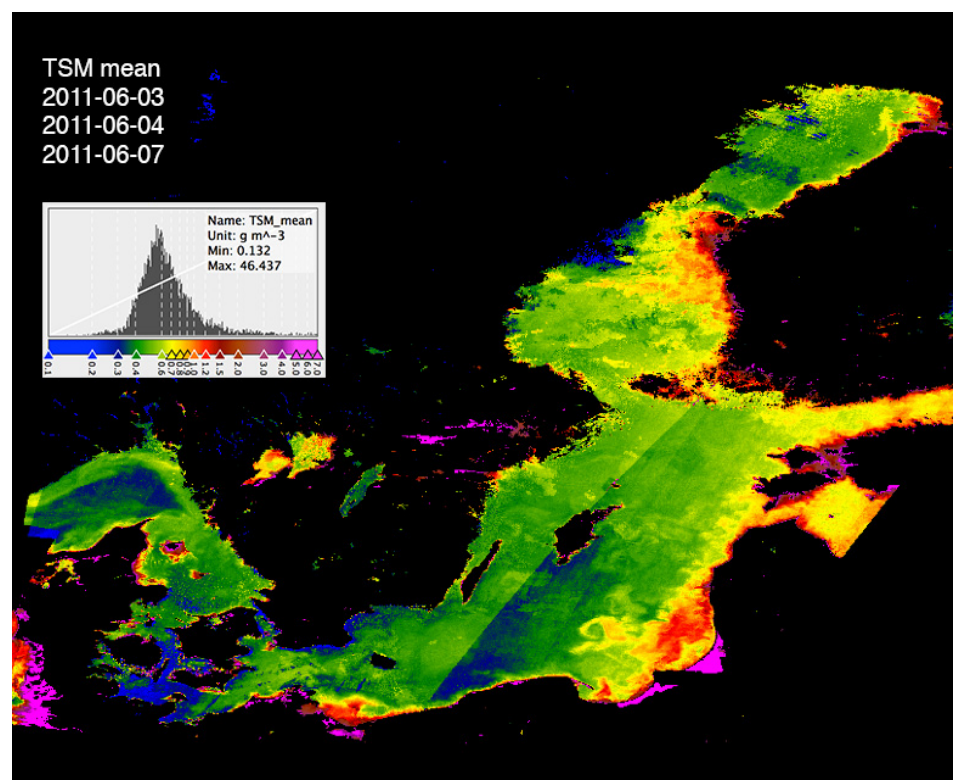

Figure 8. Early June composite from 2011 produced by binning all available scenes from early July: 2011-06-03, 2011-06-04, 201106-07.

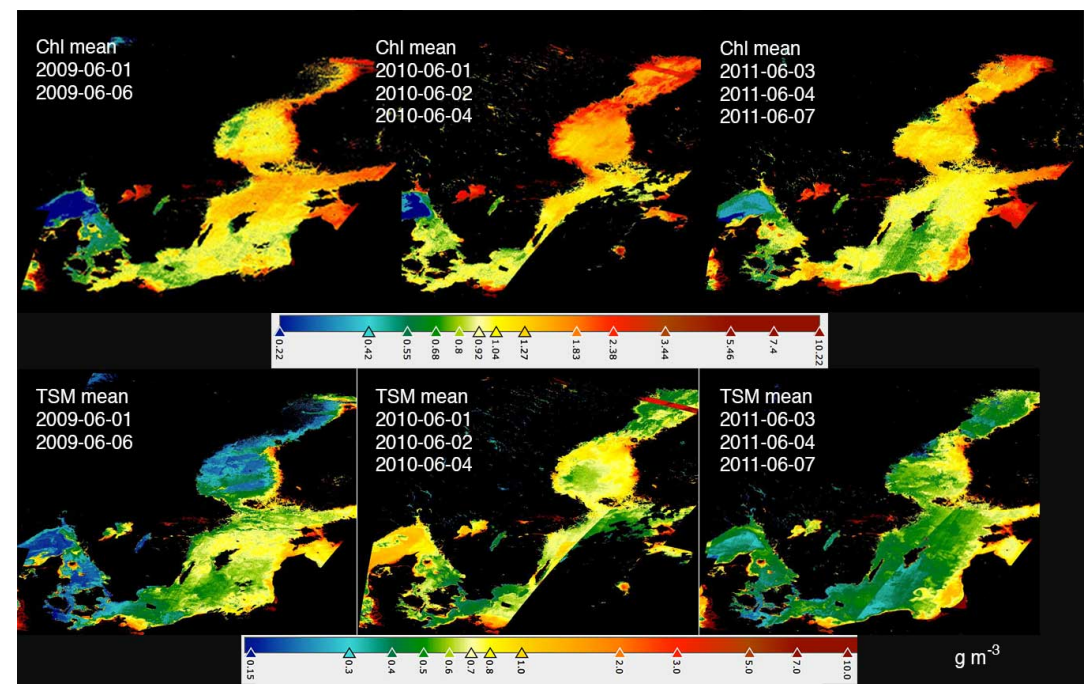

Figure 9. Comparison of chl-a and TSM concentrations and distributions in early June for the years 2009, 2010, 2011. 
Ocean Sci. Discuss., doi:10.5194/os-2016-2, 2016

Manuscript under review for journal Ocean Sci.

Published: 3 February 2016

(c) Author(s) 2016. CC-BY 3.0 License.

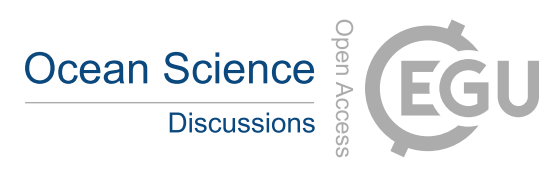

(c) (i)
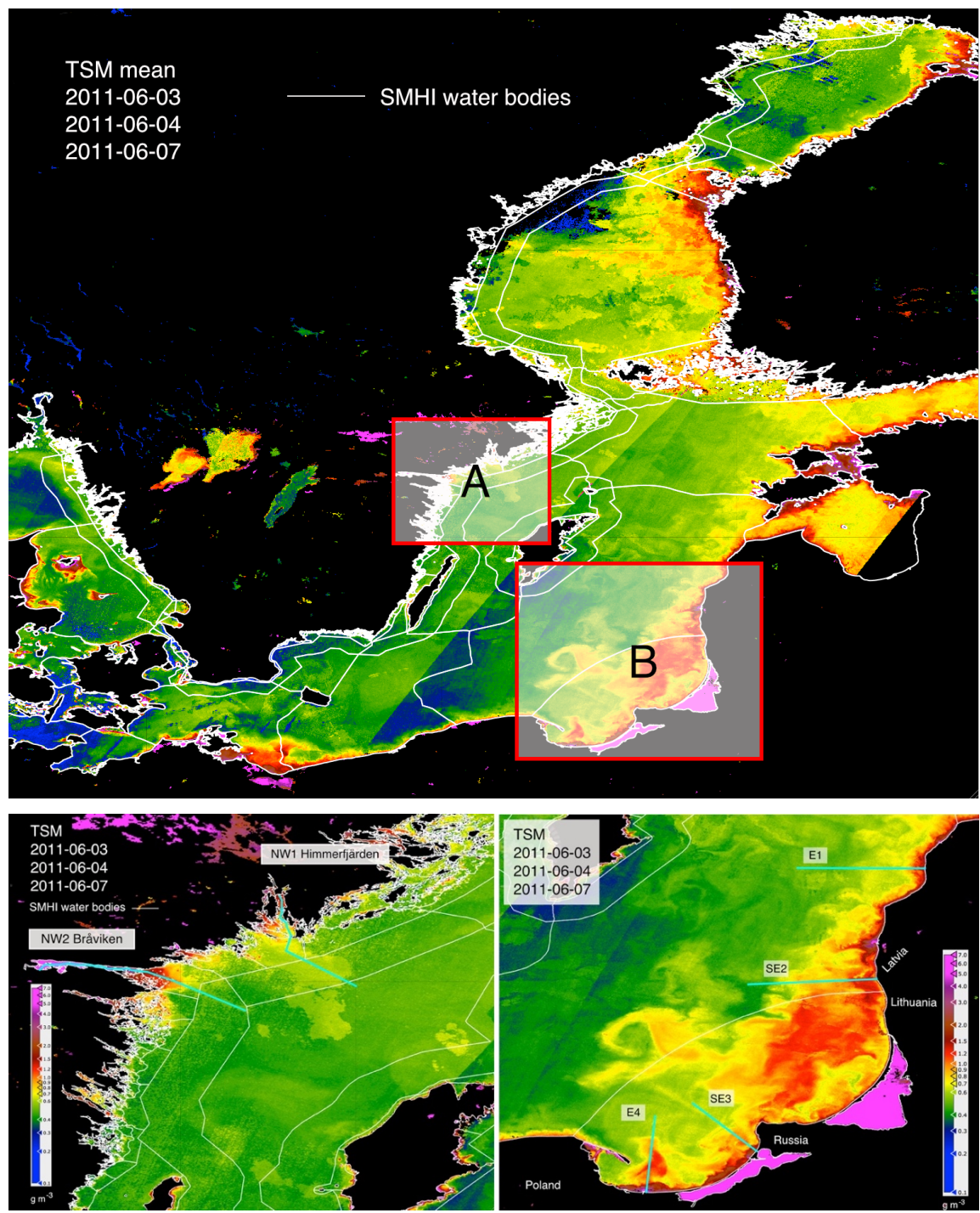

Figure 10 a. Definition of coastal zone according to SMHI $1 \mathrm{~nm}=$ coastal areas, 1-12 $\mathrm{nm}=$ outer water bodies (utsjöområden). Credits: SMHI, Basverksamheten, Information och statistic. Figure $10 \mathrm{~b}$. Definition of coastal zone according to SMHI $1 \mathrm{~nm}=$ 5 coastal areas in area A (NW Baltic Sea). Figure $10 \mathrm{c}$. Definition of coastal zone according to SMHI $1 \mathrm{~nm}=$ coastal areas in area B (S and SE Baltic Sea). 
Ocean Sci. Discuss., doi:10.5194/os-2016-2, 2016

Manuscript under review for journal Ocean Sci.

Published: 3 February 2016

(c) Author(s) 2016. CC-BY 3.0 License.

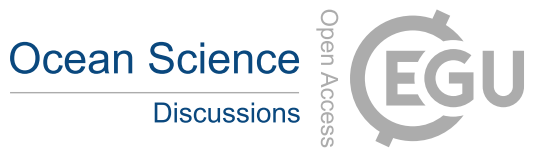

(c) (1)
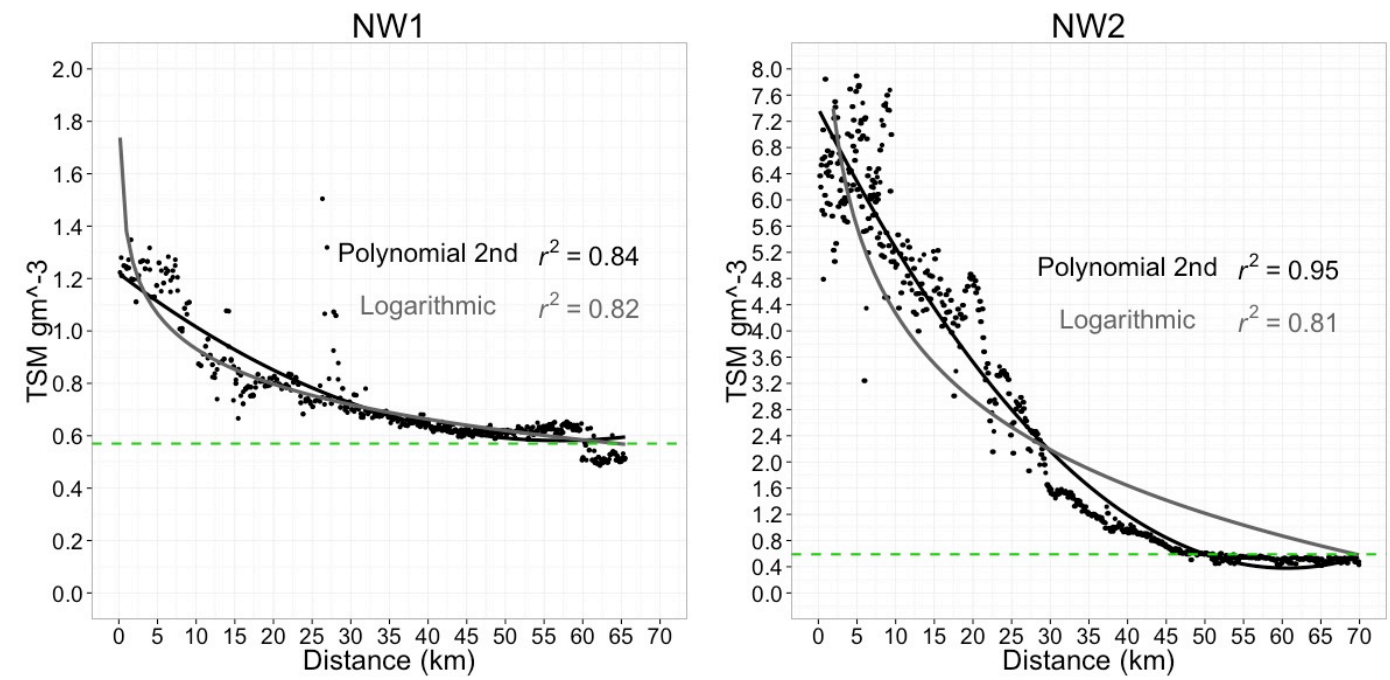

Figure 11a Extracted TSM transect from Himmerfjärden bay (NW1) and Bråviken bay (NW2). The transect started at the outlet of Himmerfjärden sewage treatment plant, and at a distance of approximate $28 \mathrm{~km}$ there is the opening into the Baltic Sea. The trend was best described by a second order polynomial, confirming the model by Kratzer and Tett (2009). The local threshold of $50.57 \mathrm{~g} \mathrm{~m}^{-3}$ was reached at a distance of about $27 \mathrm{~km}$ offshore (at about $55 \mathrm{~km}$ from the Sewage Treatment Plant). Extracted TSM transect (early June) from Bråviken bay (NW2). The trend was also best described by a $2^{\text {nd }}$ order polynomial. The transect started right outside of Norrköping and followed through the bay all the way to the open sea waters. The local threshold of $0.57 \mathrm{~g} \mathrm{~m}^{-3}$ was reached at a distance of about $50 \mathrm{~km}$, corresponding to about $15 \mathrm{~km}$ offshore. 
Ocean Sci. Discuss., doi:10.5194/os-2016-2, 2016

Manuscript under review for journal Ocean Sci.

Published: 3 February 2016

(c) Author(s) 2016. CC-BY 3.0 License.

E1

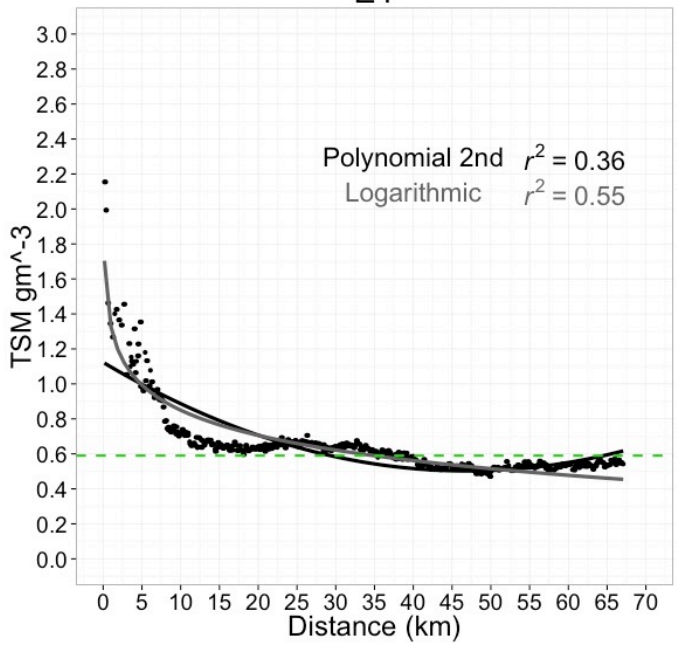

SE3

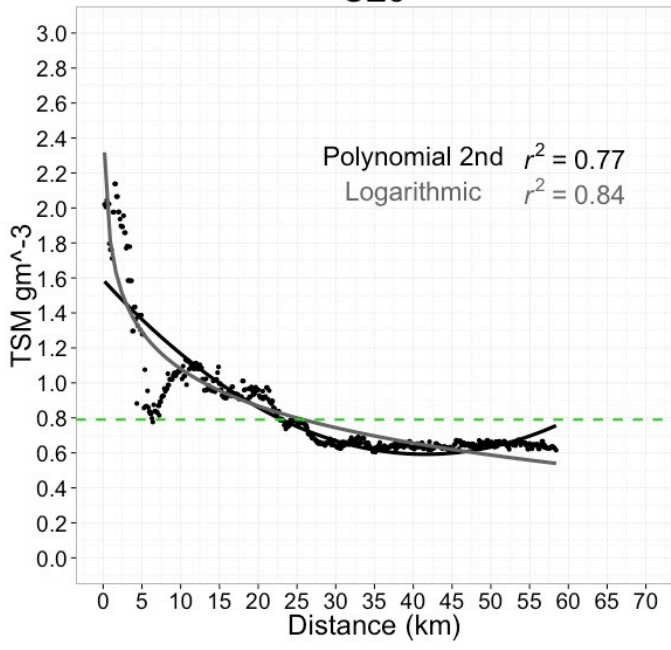

SE2

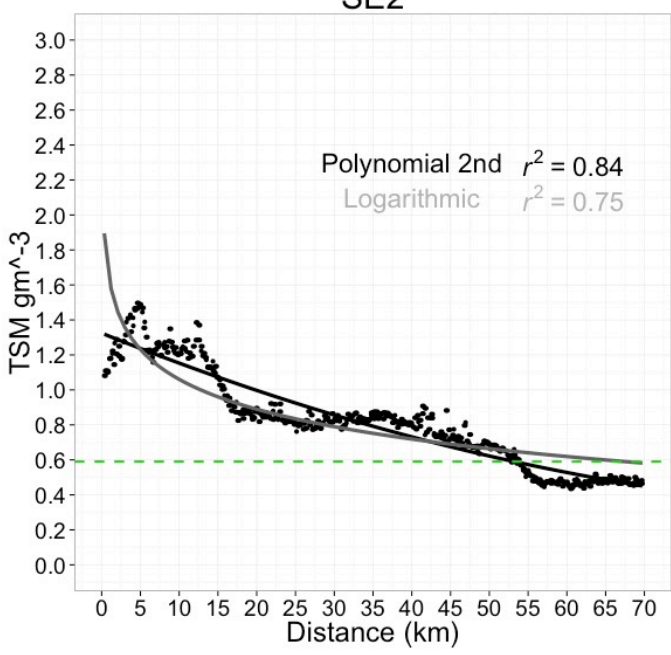

S4

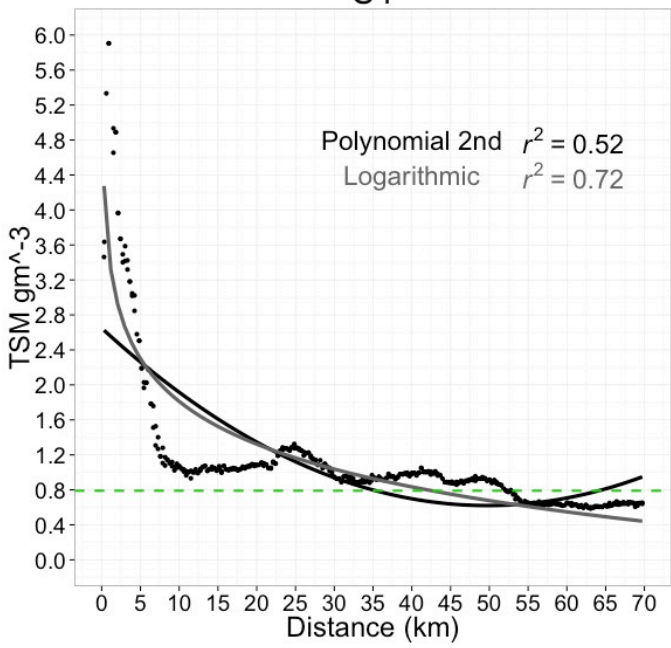

Figure 11b. Extracted TSM transect (early June) perpendicular to the Latvian coast (E1). The trend was best described by logarithmic function: $r^{2}=0.64$. The threshold of $0.59 \mathrm{~g} \mathrm{~m}^{-3}$ was reached at an approximate distance of $34 \mathrm{~km}$ off the coast. Trend analysis Latvian coast (SE2). The trend was described best by a polynomial regression of $2^{\text {nd }}$ order: $R^{2}=0.84$. There was a 5 significant difference in r-squared when compared to the logarithmic function. The local threshold of $0.59 \mathrm{~g} \mathrm{~m}^{-3}$ was reached at a distance of about $52 \mathrm{~km}$ from the coast. Trend analysis at the Russian (Kaliningrad) coast (SE3). The trend is best described by a logarithmic function: $\boldsymbol{R}^{2}=\mathbf{0 . 7 7}$. There was a significant difference when compared to polynomial. The local threshold of 0.79 $\mathrm{g} \mathrm{m}^{-3}$ was reached at a distance of $37 \mathrm{~km}$ from the coast. 
Ocean Sci. Discuss., doi:10.5194/os-2016-2, 2016

Manuscript under review for journal Ocean Sci.

Published: 3 February 2016

(C) Author(s) 2016. CC-BY 3.0 License.

Trend analysis at the Polish coast (Bay of Gdansk, S4). The trend is described by logarithmic function: $r^{2}=0.72 ;$ there was a substantial difference in r-squared when compared to the polynomial function. The local threshold of $0.79 \mathrm{~g} \mathrm{~m}^{-3}$ was reached at a distance of $43 \mathrm{~km}$ from the coast.

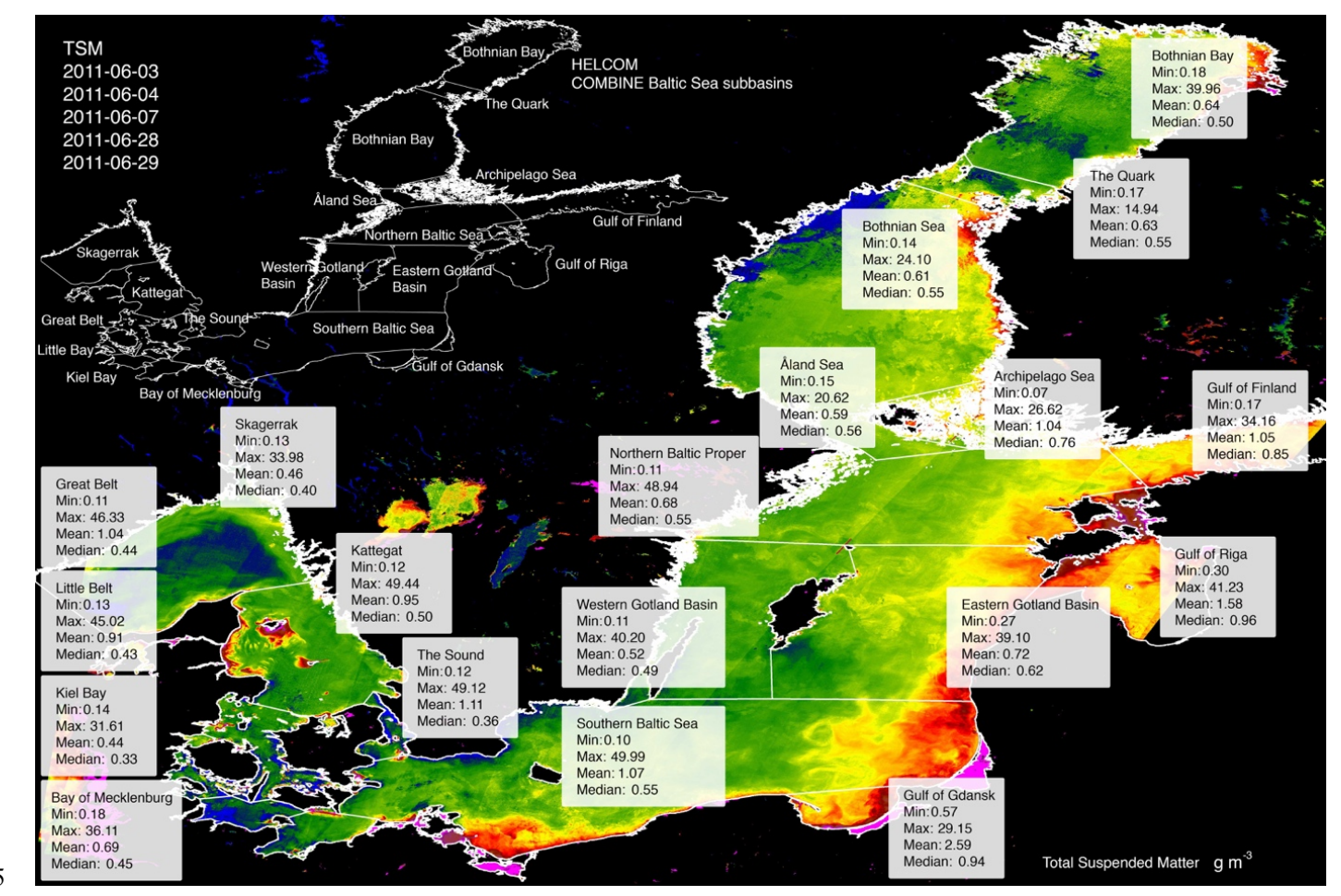

Figure 12. MERIS composite from June 2011 compiled HELCOM-defined sub-basins of the Baltic Sea with TSM monthly mean concentrations statistically represented via histograms for each basin. The Min, Max, Mean and Median values of the monthly means are shown. The ranges of values for the different basins are shown in Table 1. 
Ocean Sci. Discuss., doi:10.5194/os-2016-2, 2016

Manuscript under review for journal Ocean Sci.

Published: 3 February 2016

(c) Author(s) 2016. CC-BY 3.0 License.

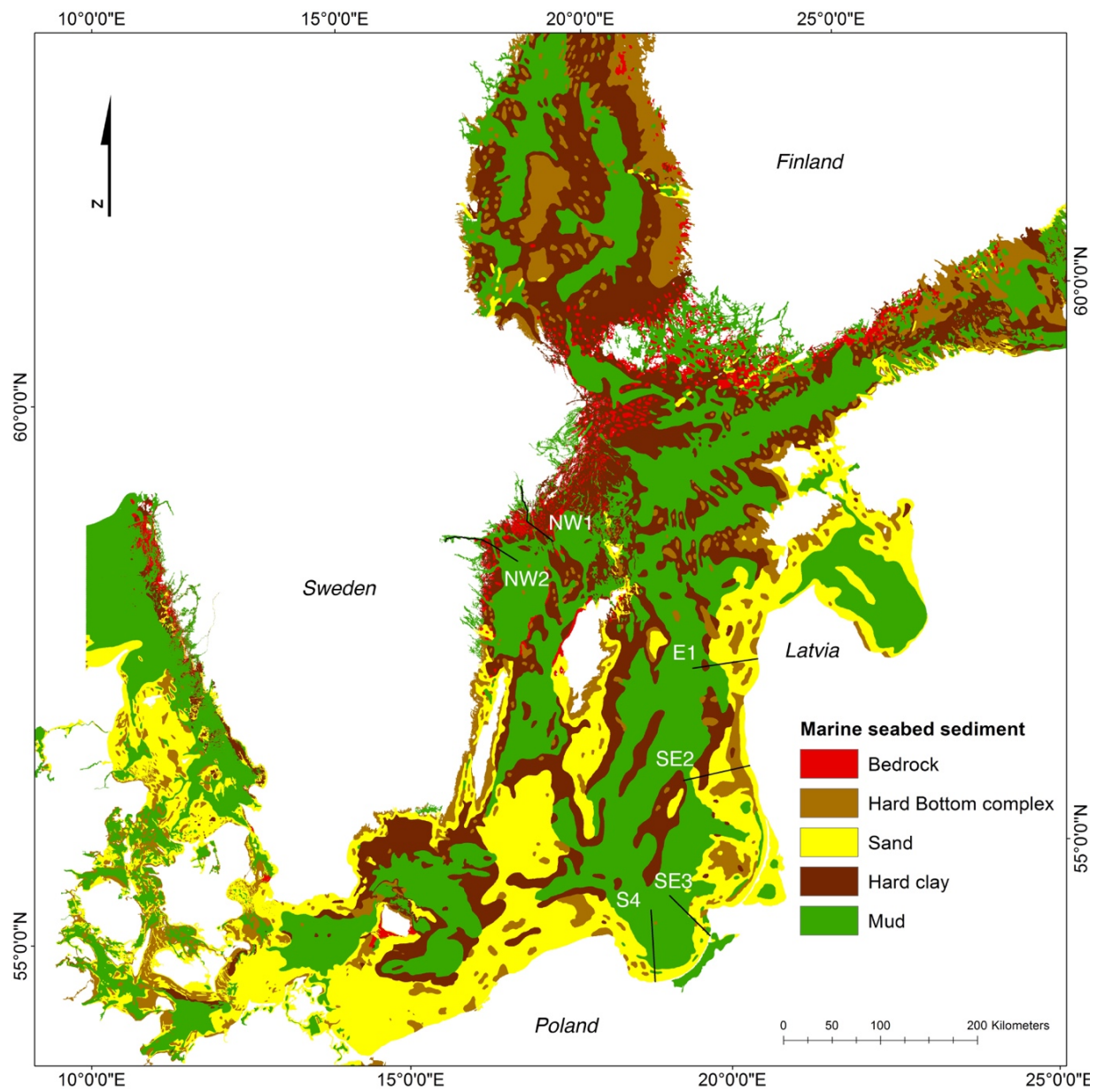

Figure 13. Baltic Sea Marine seabed sediment map. "Marine seabed sediment split into 5 categories in the Kattegat and Baltic Sea (compiled from sediment information from GEUS, GSF and SGU). The sediment composition of the seabed is considered essential in marine landscape production as it is one of the primary parameters influencing the biogeographic distribution of marine

5 benthic species and a primary component in shaping the physical structure and function of marine habitats. The resulting classification scheme consists of five sediment classes, which can be extracted from existing data. The sediment classes applied in the mapping and modelling of the Baltic Sea marine landscapes are: I. Bedrock. II. Hard bottom complex, includes patchy hard surfaces and coarse sand (sometimes also clay) to boulders. III. Sand including fine to coarse sand (with gravel exposures). IV. Hard clay sometimes/often/possibly exposed or covered with a thin layer of sand/gravel. V. Mud including gyttja-clay to gyttja-silt.

10 For more details see: BALANCE Interim Report no. 10 "Towards marine landscapes in the Baltic Sea": http://balanceeu.org/xpdf/balance-interim-report-no-10.pdf” (EU BALANCE project) downloaded from Baltic Sea data and map service provided by HELCOM (HELCOM data service). 
Ocean Sci. Discuss., doi:10.5194/os-2016-2, 2016

Manuscript under review for journal Ocean Sci.

Published: 3 February 2016

(c) Author(s) 2016. CC-BY 3.0 License.

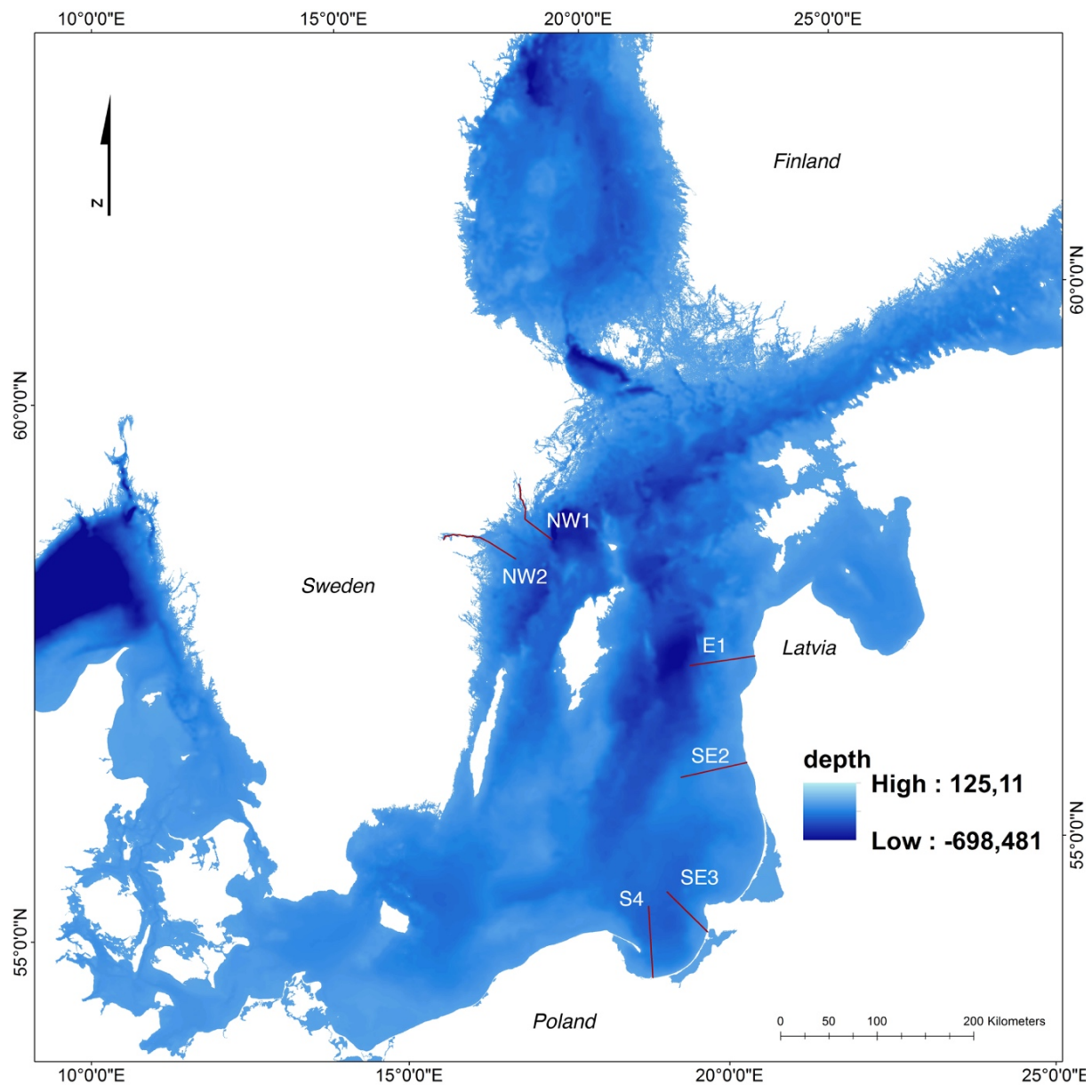

Figure 14. The Baltic Sea bathymetry map overlaid with transect shapefiles NW1, NW2, E1, SE2, SE3, S4. ("Raster grid of the Baltic Sea bathymetry computed with ArcGIS Spatial Analyst (KRIGING) from the original DIGITAL Topography of the Baltic Sea (IOWTOPO) database produced by the Baltic Sea Research Institute of Warnemunde. Output resolution of the grid is $250 \mathrm{~m}$, 5 data is projected into ERTS89_LAEA CRS (Lazmbert Azimuthal Equal Area projection, ETRS89 datum), file format is Erdas Imagine (IMG), data format is continuous, float") downloaded from Baltic Sea data and map service provided by HELCOM (HELCOM data service). 
Ocean Sci. Discuss., doi:10.5194/os-2016-2, 2016 Manuscript under review for journal Ocean Sci. Published: 3 February 2016 (c) Author(s) 2016. CC-BY 3.0 License.

\section{(c) (1)}
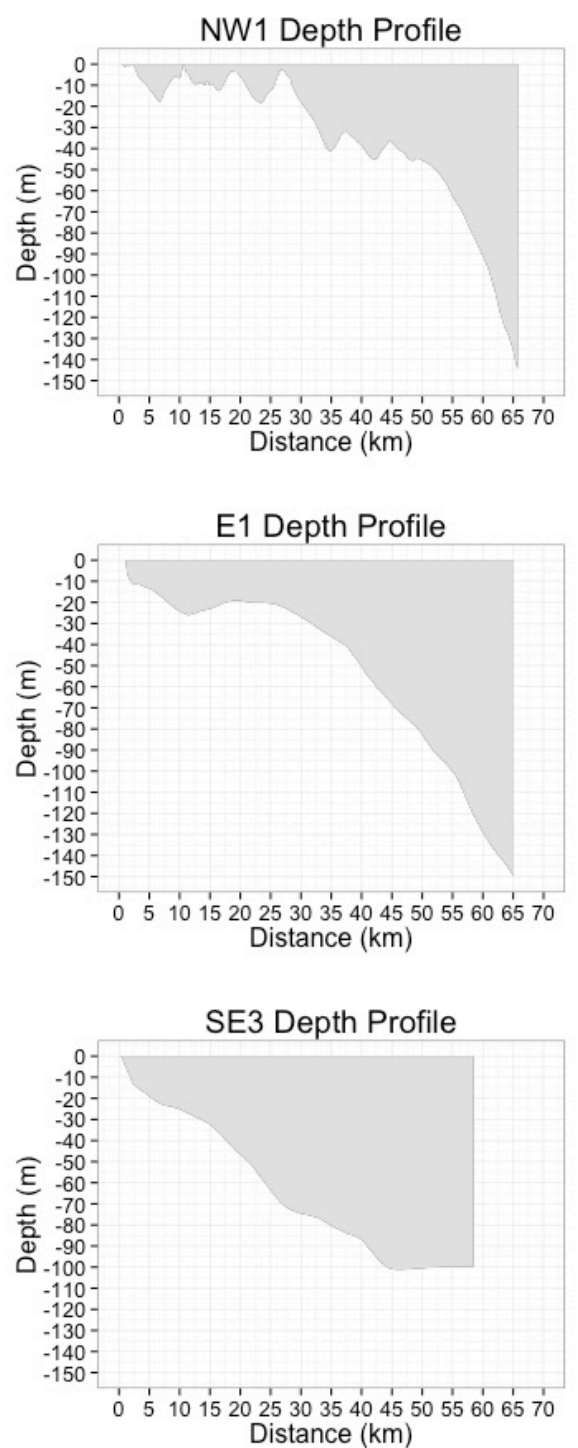
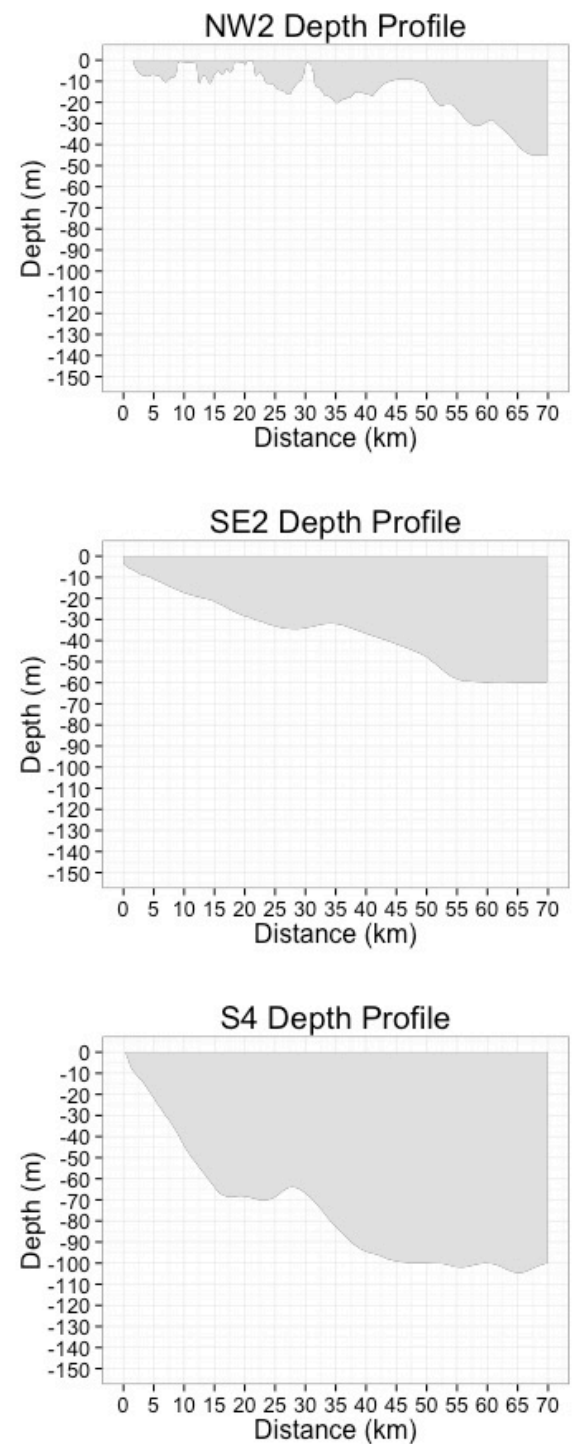

Figure 15. Depths profiles for the chosen coastal-off-shore transects for different areas of the Baltic Sea. The TSM concentrations were extracted from MERIS data along the same transects and their trend lines (Figures 11 a-b) were then compared to the given 5 depth profiles. The depth profiles were obtained from The Baltic Sea bathymetry by HELCOM and IOW (maps.helcom.fi). 